\title{
The Devonian/Carboniferous boundary in the Holy Cross Mountains (Poland)
}

\author{
Jan MALEC ${ }^{1, *}$ \\ 1 Polish Geological Institute - National Research Institute, Holy Cross Mountains Branch, Zgoda 21, 29-953 Kielce, Poland
}

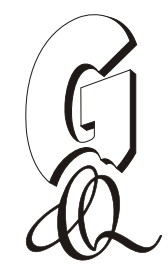

Malec, J., 2014. The Devonian/Carboniferous boundary in the Holy Cross Mountains (Poland). Geological Quarterly, 58 (2): 217-234, doi: 10.7306/gq.1142

Five sections from the Kielce Region of the Holy Cross Mountains and one core from a borehole drilled in the nearby western Mesozoic Margin reveal the best recognized deposits from the Devonian/Carboniferous boundary interval. In four sections: Ruda Strawczyńska, Bolechowice IG 1, Zaręby IG 2 and Kowala, the Devonian/Carboniferous boundary is located within a continuous series of deep-water carbonates, whereas in the two remaining: Ostrówka Quarry and the Jabłonna IG 1 borehole, the Devonian/Carboniferous boundary interval contains stratigraphic gaps resulting from lack of deposition in submarine conditions. The biostratigraphic position of the analysed uppermost Devonian and lowermost Carboniferous succession is determined by assemblages of conodonts, microspores and deep-water ostracodes of the Thuringian ecotype. A distinctive succession of contemporaneous fauna assemblages and lithofacies types is traceable from Holy Cross Mts. to Rhenish Massif. The main extinction occurred during a transgression-promoted anoxia, which then reverted in glacigenic regression. The anoxic conditions are well-expressed at Bolechowice and Kowala successions.

Key words: Holy Cross Mountains, Devonian/Carboniferous boundary, biostratigraphy.

\section{INTRODUCTION}

The Devonian/Carboniferous boundary has been an intriguing problem in the Holy Cross Mountains ever since Carboniferous deposits were recognized in the Gałęzice area (Czarnocki, 1916); their occurrence is restricted only to the Kielce Region (Czarnocki, 1950; Szulczewski, 1995). The stratigraphy of the Devonian/Carboniferous boundary interval of the Gałęzice area, worked out in detail by Czarnocki (1928), indicated the presence of Upper Famennian limestones with Wocklumeria and the lack of the Gattendorfia Zone, which at that time was assigned to the uppermost Famennian. According to Czarnocki (1928), the lack of the uppermost Famennian in the western part of the Holy Cross Mountains was the result of breaks in sedimentation between the Devonian and Carboniferous, caused by one of the phases of the Variscan Orogeny. Moreover, he stated that there is a sedimentary continuity between the Devonian and Carboniferous in the central part of the Holy Cross Mountains, in the "Łagów-Kielce depression" and in the Gałęzice-Bolechowice Syncline. In the latter unit, near Kowala, Czarnocki $(1933,1989)$ documented a complete succession across the discussed boundary. Field work allowed to expose limestones with ammonoids of the Wocklumeria and Gattendorfia zones, above which were distinguished grey shales, siliceous shales and lidites, representing the Lower Carboniferous Culm facies.

*E-mail: jan.malec@pgi.gov.pl

Received: May 17, 2013; accepted: December 20, 2013; first published online: December 31, 2013
The stratigraphic position of deposits from the Devonian/Carboniferous boundary interval of the Gałęzice area as well as those subsequently recognized in other areas of the Kielce Region, was during later studies precisely determined on the basis of conodonts; these fossils allowed for a better biostratigraphic resolution than the ammonoids (Freyer and Żakowa, 1967; Wolska, 1967; Szulczewski, 1971, 1978, 1981; Dzik, 1997, 2006). Conodont studies have revealed the presence of several stratigraphic gaps in the Devonian/Carboniferous boundary interval in the Gałęzice area, both in the Upper Devonian and Lower Carboniferous layers, encompassing even up to several conodont zones, as well as deposits containing mixed conodont assemblages from several zones (Szulczewski and Żakowa, 1976; Szulczewski, 1978, 1981, 1982). Conodont analysis of neptunian dykes from the western part of the Holy Cross Mountains indicated areas that at present lack uppermost Devonian and Lower Carboniferous deposits but which were originally covered by deep-water deposits (Szulczewski, 1973).

Some borehole sections from the western part of the Holy Cross Mountains have documented an almost complete conodont succession across the Devonian/Carboniferous boundary (Freyer and Żakowa, 1967; Żakowa, 1967). In turn other sections have indicated stratigraphic gaps in the Upper Famennian - Lower Tournaisian (Żakowa et al., 1983). In borehole sections where Famennian carbonates are in direct contact with Lower Carboniferous siliceous shales, usually a sedimentary discontinuity or tectonic contact of the Famennian and Tournaisian was assumed (Żakowa, 1970, 1971a; Jurkiewicz, 1971; Pawłowska and Pawłowski, 1978).

Detailed litho- and biostratigraphy of the Devonian/Carboniferous boundary interval has been worked out only for a few areas in the Kielce Region. They include sections in the vicinity of 


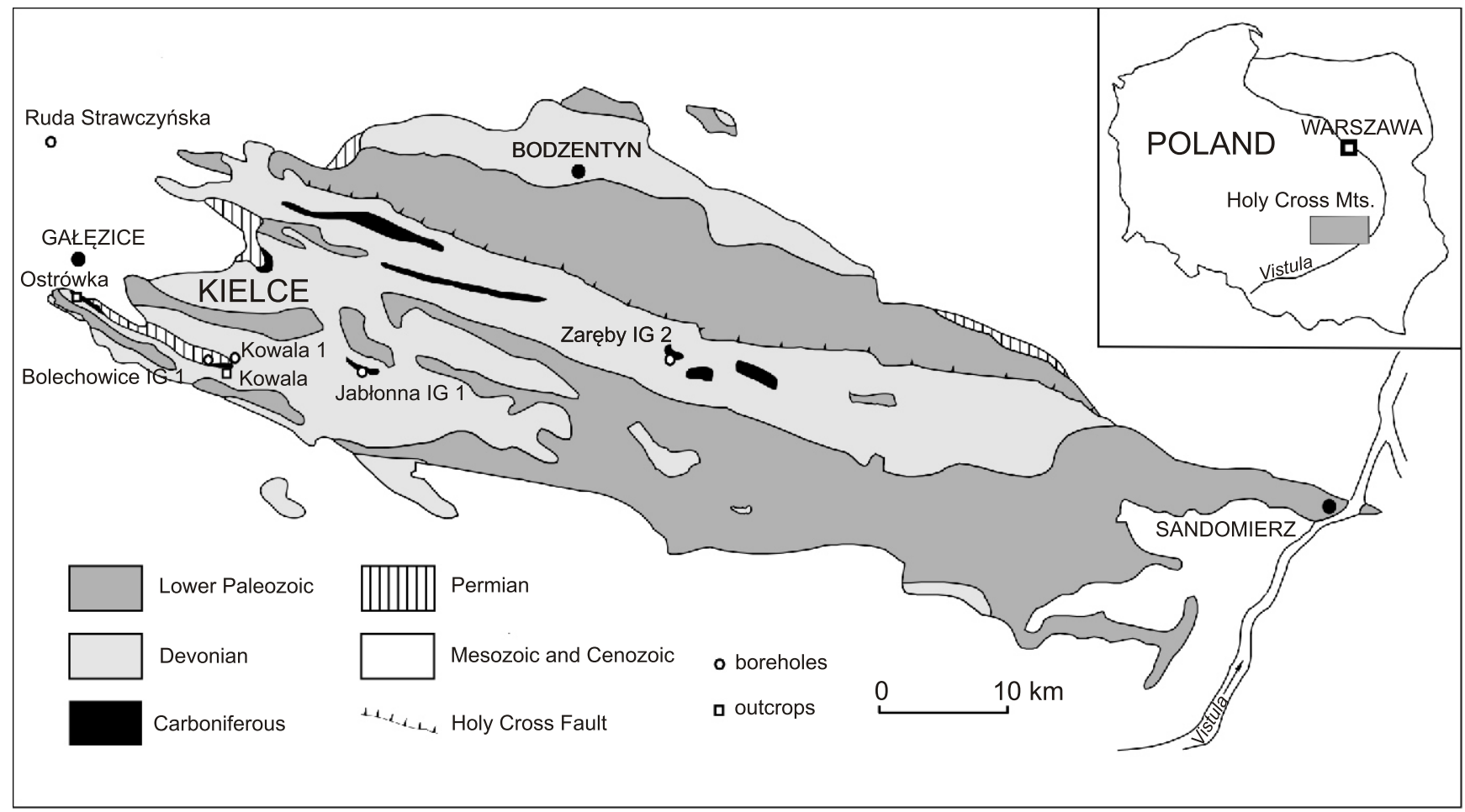

Fig. 1. Location of the investigated and discussed outcrops and boreholes in the Holy Cross Mountains

Gałęzice (Ostrówka Quarry), Kowala, Bolechowice, Jabłonna and Zaręby near Łagów, as well as the core section of the Ruda Strawczyńska borehole, located in the nearby western Mesozoic Margin in the elongation of the Kielce-Łagów Synclinorium (Figs. 1 and 2).

\section{OSTRÓWKA QUARRY}

Near Gałęzice (Fig. 1), the Devonian/Carboniferous boundary interval recognized in detail in several sections from the Ostrówka Quarry (Fig. 2). On Frasnian amphiporoid limestones, along a karst erosional surface, with a distinct angular unconformity, occur Famennian ammonoid limestones, from several tens of centimetres to about $4 \mathrm{~m}$ thick, that are rich in ammonoids, crinoids, trilobites, corals, bivalves, snails, brachiopods and fish remains (Szulczewski, 1981; Szulczewski et al., 1996; Skompski and Szulczewski, 2000; Skompski et al., 2006).

The Famennian complex is condensed and contains stratigraphic gaps. The condensed limestones terminate in the Lower or Middle expansa Zone and locally reach to the praesulcata Zone. In the lower part of the Famennian occur deposits from the marginifera-trachytera zones. The Famennian succession does not contain conodonts of the postera Zone. This regularity is also observed in other sections with condensed Famennian strata in the Holy Cross Mountains. The stratigraphic gap at the Famennian/Tournaisian boundary encompasses the Middle praesulcata-sandbergi zones (Fig. 2). The origin of these gaps is not linked with tectonic events but with local non-deposition in submarine conditions. The limited nature of the stratigraphic gaps is indicated by the presence of deposits from the missing intervals as well as admixtures of conodonts from the missing conodont zones (Szulczewski, 1978, 1981; Szulczewski et al., 1996).

Above the condensed beds from the Devonian/Carboniferous boundary interval occur several characteristic Lower Carboniferous lithostratigraphic units (Fig. 2):
RADLIN BEDS (RB)

Deposits of this unit include green-grey claystones with thin intercalations of pyroclastic rocks, marls and limestones, which occur either on condensed Famennian limestones or directly on Frasnian amphiporoid limestones, with a stratigraphic gap encompassing the Devonian/Carboniferous boundary. The limestones and marls contain goniatites, trilobites, crinoids, brachiopods and corals (Osmólska, 1962; Szulczewski, 1981; Czarniecki, 1992; Szulczewski et al., 1996). In the Ostrówka Quarry, the deposits are up to 3.5 m thick (Skompski, 1992; Szulczewski, 1995; Szulczewski and Skompski, 1995; Skompski et al., 2006). They contain Upper Tournaisian conodonts from the anchoralis Zone (Szulczewski, 1978). Conodont analysis indicates that the oldest deposits of the Radlin Beds are from the sandbergi Zone and the youngest - from the texanus Zone, i.e. they encompass almost the entire Tournaisian and the entire lowermost Visean (Szulczewski et al., 1996).

\section{ZARĘBY BEDS (ZB)}

This unit is developed as black siliceous claystones with radiolarians and phosphorus concretions (Culm facies), up to $25 \mathrm{~m}$ thick, that occur conformably on the clayey-marly Radlin Beds (Łydka and Żakowa, 1975; Żakowa and Migaszewski, 1995; Szulczewski et al., 1996). In the Ostrówka Quarry, the stratigraphic position of these deposits is based on radiolarians and points to the Lower-Middle Visean (Żakowa and Paszkowski, 1989); in the conodont zonation their age ranges from the texanus to the bilineatus zones (Szulczewski et al., 1996). They represent the deepest Carboniferous facies in the Gałęzice area.

\section{GAłĘZICE DEBRITE BEDS (GDB)}

Deposits of this unit, distinguished by Żakowa and Migaszewski (1995), occur with a sedimentary unconformity on 


\section{Ostrówka}

Quarry

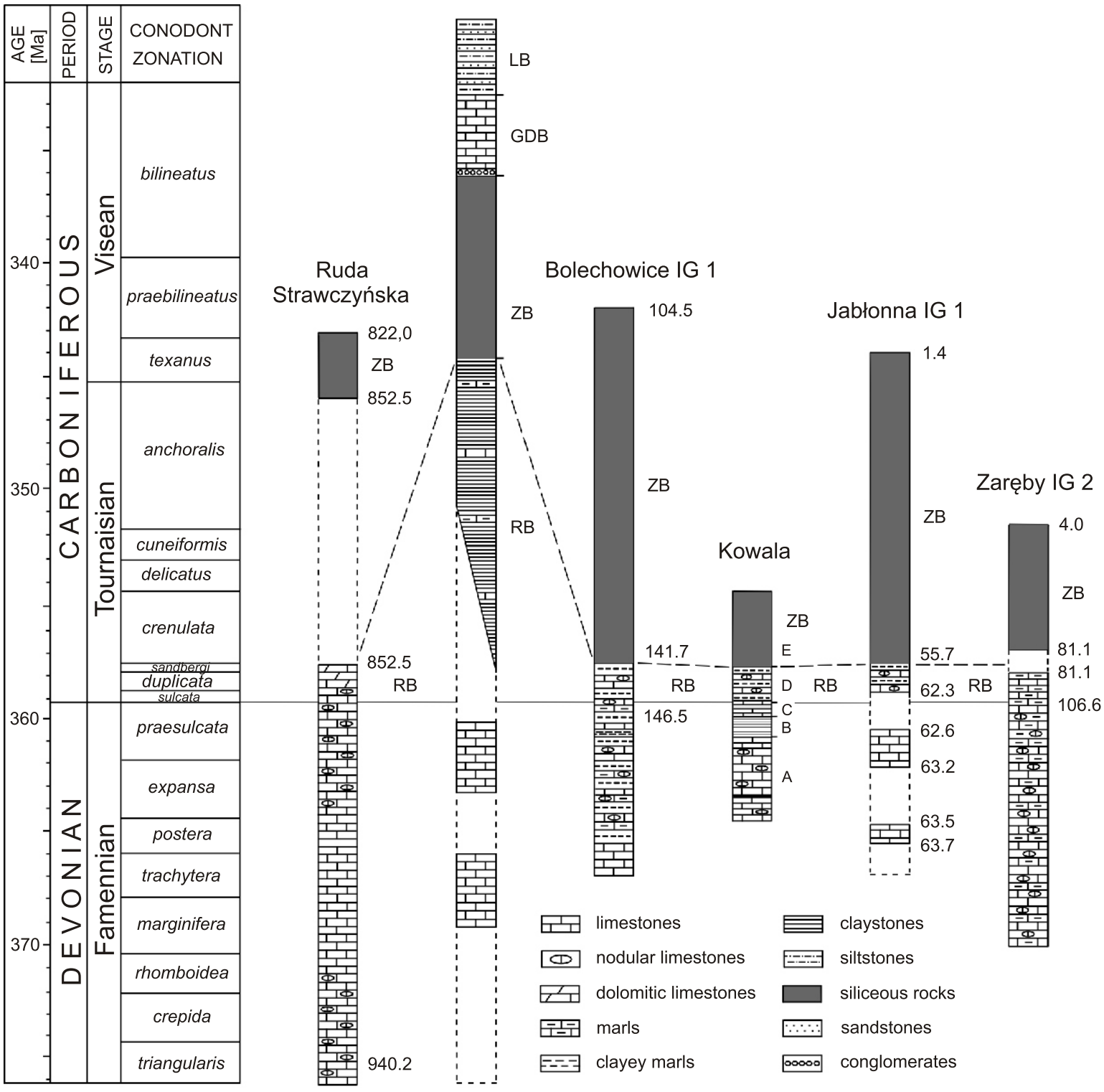

Fig. 2. Lithologic profiles from the Devonian and Carboniferous boundary in the Holy Cross Mountains

Absolute time scale after Davydov et al. (2004), Gradstein and Ogg (2004) and Kaufmann (2006); the conodont zonation after Wendt et al. (2009); A-E - lihological complexes at Kowala section; Carboniferous lithostratigraphic units: RB - Radlin Beds; ZB - Zaręby Beds; GDB - Gałęzie Debrite Beds; LB - Lechówek Beds

siliceous claystones of the Zaręby Beds (Bełka and Skompski, 1988; Belka et al., 1996; Skompski, 2006). In the base, occur breccia from several tens of centimetres to $2 \mathrm{~m}$ thick; the overlying bedded limestones, up to $12 \mathrm{~m}$ thick, contain a rich fauna of corals, goniatites, brachiopods, foraminifers and crinoids (Kwiatkowski, 1959; Fedorowski, 1971; Czarniecki, 1973; Łydka and Żakowa, 1975; Żakowa, 1976; Jurkiewicz and Żakowa, 1978; Belka et al., 1996; Szulczewski et al., 1996; Skompski et al., 2006). Limestones overlying the breccia represent the Carboniferous Limestone facies. These deposits have been resedimented as gravitational flows of detrital material from the margin of a carbonate platform to the basin. The redeposited carbonate sediments were transported from the south from the so-called Nida Platform (Bełka and Skompski, 1988; Belka et al., 1996; Skompski, 2006). Pelagic limestones from the topmost part of the redeposited limestones contain cono- donts of the bilineatus Zone (Szulczewski et al., 1996; Skompski et al., 2006).

\section{LECHÓWEK BEDS (LB)}

This unit comprises siltstones and fine- and medium-grained greywacke sandstones with intercalations of clayey shales, clayey siderites, clayey-siliceous shales and phosphoritic concretions (Łydka and Zakowa, 1975). It contains pelagic fauna represented by goniatites, nautiloids and hyolithids as well as plant debris. Goniatites indicate the Upper Visean Goniatites granosus Zone (Żakowa, 1971b). They occur with sedimentary continuity on the organodetrital limestones of the Gałęzice Debrite Beds (Szulczewski and Skompski, 1995; Żakowa and Migaszewski, 1995). In the Gałęzice area they reach a thickness of about $150 \mathrm{~m}$. 


\section{BOLECHOWICE IG 1 BOREHOLE}

The Bolechowice IG 1 Borehole was drilled in 1961 in the southwestern part of the Kielce Region, in the Gałęzice-Bolechowice Syncline (Fig. 1). Carboniferous and Upper Devonian rocks were recognized between 104.5-212.0 m below the Permian (Zechstein) strata. Żakowa (1967) distinguished several main lithological units in the Carboniferous and Devonian (Fig. 2) succession of the core:

- 104.5-141.7 m - siliceous and clayey-siliceous shales,

- 141.7-152.4 m - clayey marls with limestone nodules,

- 152.4-153.4 m - black marls,

- 153.4-170.3 m - marls and limestones,

- 170.3-212.0 m - massive, fine-crystalline limestones with stromatoporoids.

The clayey-siliceous deposits between 104.5-141.7 m represent the Lower Tournaisian and lowermost Visean Zaręby Beds (Żakowa, 1967). Carbonate deposits from 141.7-146.5 m correspond to the Lower Carboniferous Radlin Beds (Żakowa and Migaszewski, 1995). Marl-carbonate deposits from 146.5-170.3 $\mathrm{m}$ are the lithostratigraphic equivalent of the upper part of the marly series distinguished in the Famennian of the Kowala 1 core (Romanek and Rup, 1990). Below, at 170.3-212.0 m, occur limestones with stromatoporoids, assigned to the Upper Frasnian part of the Kowala Formation (Narkiewicz et al., 1990; Romanek and Rup, 1990; Racki, 1993; Szulczewski, 1995).

Conodont and microspore studies have indicated that the beginning of deposition of the Zaręby Beds in this core is most probably in the Middle Tournaisian crenulata Zone (Freyer and Żakowa, 1967; Filipiak, 2004). Marls with limestone nodules contain Lower Carboniferous conodonts: at $141.7 \mathrm{~m}$ Siphonodella isosticha (Cooper), and at $145.5 \mathrm{~m}-\mathrm{S}$. duplicata (Branson et Mehl) and S. cf. obsoleta Hass (Freyer and Zakowa, 1967). These species indicate the duplicata or sandbergi zones of the Lower Tournaisian (compare Clausen et al., 1989). Deposits of the Upper Famennian Wocklumeria Zone (Middle expansa-Middle praesulcata Conodont zones) occur at 147.5-150.0 m and were documented by conodonts at $147.5 \mathrm{~m}$ (Freyer and Żakowa, 1967). The Devonian/Carboniferous boundary, determined on the basis of conodonts occurs most probably in the depth interval of 145.5-147.5 m (Freyer and Żakowa, 1967). According to Żakowa (1967), the boundary is within the interval of $146.0-147.0 \mathrm{~m}$. Microspore analysis indicates that the boundary is near the depth of $145.0 \mathrm{~m}$, within carbonates developed as green marls with light-coloured limestone nodules and lenses, corresponding to the basal part of the Radlin Beds (Filipiak, 2004). Sedimentary continuity between the Wocklumeria Zone limestones and the marl-carbonate deposits of the Radlin Beds indicates a complete succession of beds of the Devonian/Carboniferous boundary interval in the Bolechowice IG 1 core.

\section{KOWALA}

Near Kowala (Fig. 1), beds of the Devonian/Carboniferous boundary interval have been recognized by Czarnocki (1933) in trenches, where he was able to document sedimentary continuity between the two systems. Czarnocki (1933) noted the presence of a 2-3 m thick complex of clayey-sandy green shales and varicoloured shales with the goniatites Imitoceras lying on limestones and marls of the Wocklumeria Zone. Above were documented grey-red limestones of the Gattendorfia Zone with rare Imitoceras, $0.9 \mathrm{~m}$ thick, which were assigned to the lowermost Carboniferous (Czarnocki, 1989).

In 1982, an exploratory borehole (Kowala 1) drilled in the vicinity of Kowala pierced beds from the Devonian/Carboniferous boundary interval (Rubinowski et al., 1983; Turnau, 1985, 1990; Żakowa et al., 1985; Nehring-Lefeld, 1990; Romanek and Rup, 1990). Later studies have shown that the topmost part of the drilled succession does not include Carboniferous deposits, whereas the Devonian succession lacks the uppermost Famennian (Malec et al., 1995). An exploratory trench dug in 1991 in Kowala through beds encompassing the Devonian/Carboniferous boundary exposed a continuous succession of deposits from the Upper Famennian to the Lower Tournaisian. Several rock complexes with a diverse lithology have been distinguished herein (Malec and Migaszewski, 1992; Malec, 1993a, b, 1995; Malec et al., 1995); they are presented in stratigraphic order below (Figs. 2 and 3):

A. Biomicritic, partly nodular limestones, with intercalations of marly shales, exposed at a thickness of ca. $15 \mathrm{~m}$. A ca. $30 \mathrm{~cm}$ thick bed of black bituminous shales is present in the lower part of the succession. Grey marly shales (4 cm thick) occur over limestones in the upper part of the complex. In its topmost part, calcareous concretions represent the uppermost locality with ammonoids of the Wocklumeria sphaeroides Zone.

B. Yellow-beige and grey clayey shales with pyroclastic material and abundant planktonic ostracodes - entomozooids. In the middle part of the complex occurs a $22 \mathrm{~cm}$ thick bed of compact claystones with abundant Acutimitoceras (Fig. 3, bed 159). Directly above, at an interval of about $80 \mathrm{~cm}$, within claystones, five quartz wacke beds varying from 2 through $10 \mathrm{~cm}$ in thickness occur. The thickness is ca. $2.7 \mathrm{~m}$.

C. Micritic limestones, massive and grey in the lower part and horizontally laminated and cherry-red in the upper part of the complex. Limestone beds are separated by thin layers of marly shales. The thickness reaches ca. $1.3 \mathrm{~m}$.

D. Marly-limestone beds, ca. $18 \mathrm{~m}$ thick, with thin layers rich in pyroclastic material. The lower part is composed of $6 \mathrm{~m}$ thick green-grey clayey marls, the middle part - of $6.8 \mathrm{~m}$ thick clayey marls with thin beds of grey biomicritic limestones, and the topmost part - of 5.3 m thick green and green-grey clayey marls.

E. Black clayey-siliceous and clayey-phosphatic-siliceous shales, exposed at a distance of ca. $15 \mathrm{~m}$.

Deposits included in complex A correspond to nodular limestones, i.e. the uppermost lithostratigraphic unit distinguished in the Uppermost Famennian of the Kowala 1 borehole from the interval between 10.1-21.4 m (Romanek and Rup, 1990) and set $L$ according to Devleeschouwer et al. (2013) in the Kowala section. Clayey shales of complex $B$ are the equivalent of green clayey-sandy shales with Imitoceras, distinguished in the Kowala section by Czarnocki (1933). Micritic limestones of complex $\mathrm{C}$ are comparable to the grey-red limestones with rare Imitoceras, assigned by Czarnocki (1933) to the Gattendorfia Zone. In the Koweala section, the last two complexes are distinguished as unit M (Devleeschouwer et al., 2013). Deposits of complex D correspond to the Radlin Beds (set $\mathrm{N}$ after Devleeschouwer et al., 2013), and of complex E - to the Zaręby Beds (Żakowa, 1981; Żakowa and Migaszewski, 1995).

Biostratigraphic analysis of the Devonian/Carboniferous boundary interval in Kowala included studies of conodonts (Figs. 3-6), cephalopods, ostracodes and microspores (Malec and Migaszewski, 1992; Malec, 1993a, b, 1995; Dzik, 1997, 2006; Olempska, 1997; Filipiak, 2004, 2005).

The topmost ca. $2 \mathrm{~m}$ thick part of complex A, represented by Wocklumeria Zone limestones yields a conodont assemblage (Fig. 3), which co-occurrence indicates the boundary between the Upper expansa and Lower praesulcata zones (see Ziegler and Sandberg, 1984a, b; Kürschner et al., 1993). 


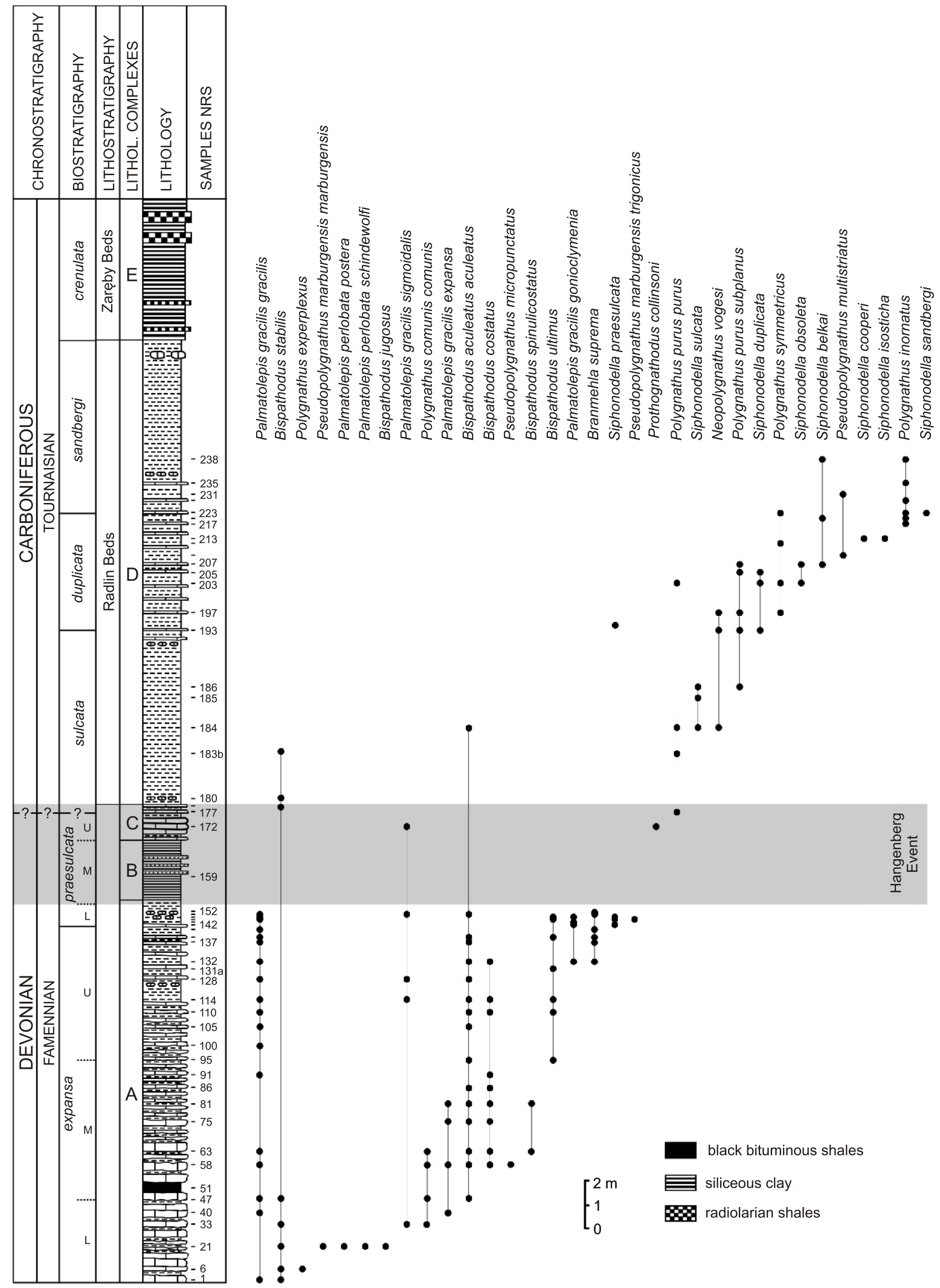

Fig. 3. Conodont biostratigraphy of the Devonian-Carboniferous boundary at Kowala section

Other explanations as in Figure 2 



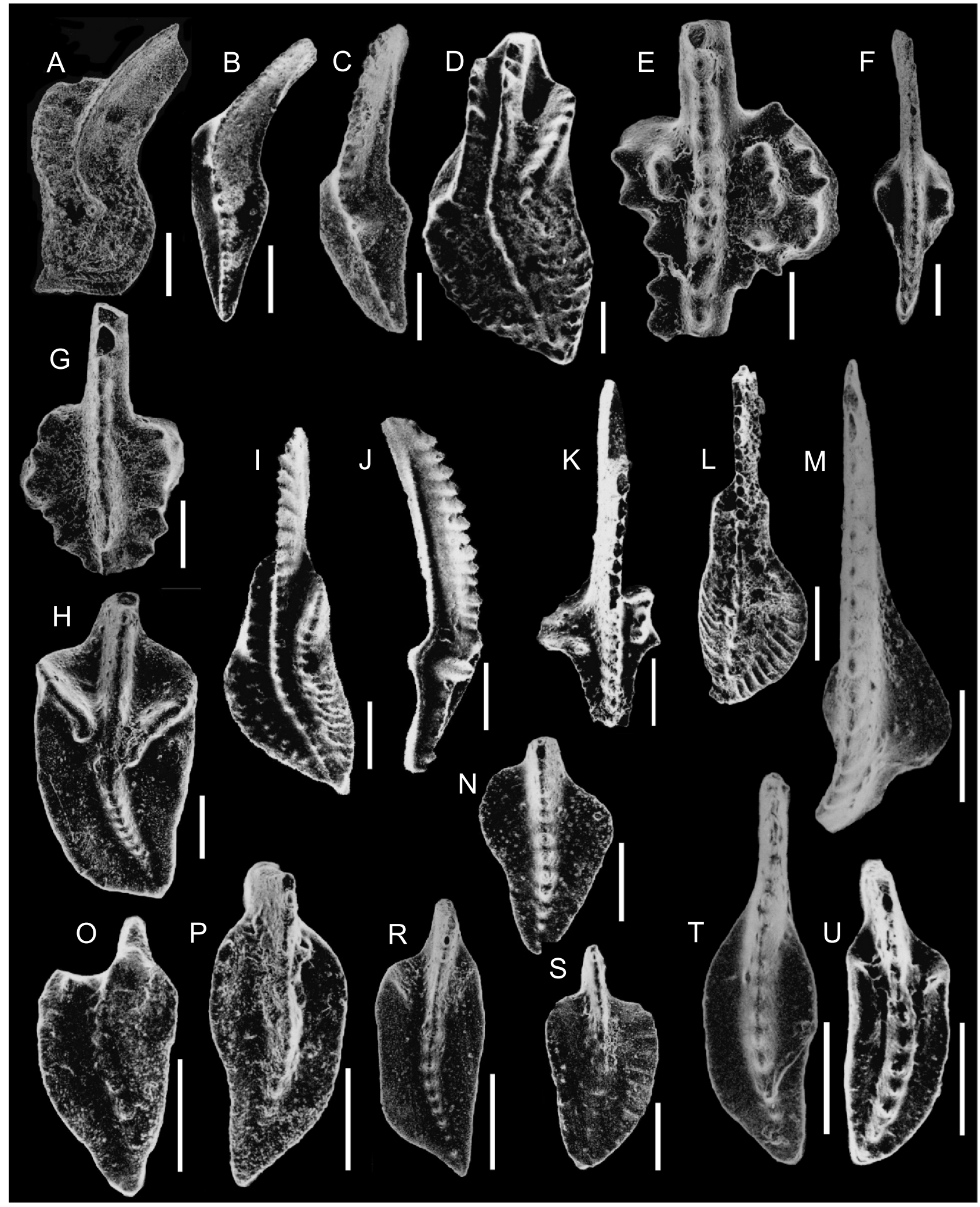

Fig. 5. Conodonts from the highest Famennian and basal Tournaisian of the Kowala trench

A - Palmatolepis perlobata postera Ziegler, sample 21; B, C - Palmatolepis gracilis expansa Sandberg and Ziegler: B - sample 81, C - sample 58; D - Polygnathus experplexus Sandberg and Ziegler, sample 6; E-G - Pseudopolygnathus marburgensis marburgensis Bischoff and Ziegler, sample 21; H - Neopolygnathus vogesi (Ziegler), sample 197; I - Polygnathus sp., sample 6; J - Palmatolepis gracilis gracilis Branson and Mehl, sample 63; K - Pseudopolygnathus micropunctatus Bischoff et Ziegler, sample 58; L - Polygnathus sp., sample 1; M Branmehla suprema (Ziegler), sample 140; N, R - Polygnathus purus subplanus Voges: N - sample 197, R - sample 203; O, P Polygnathus purus purus Voges: O - sample 193, P - sample 197; S - Polygnathus sp., sample 217; T - Polygnathus communis communis? Branson and Mehl, sample 47; U - Polygnathus communis communis Branson and Mehl, sample, 58; scale bar - $200 \mu \mathrm{m}$ 


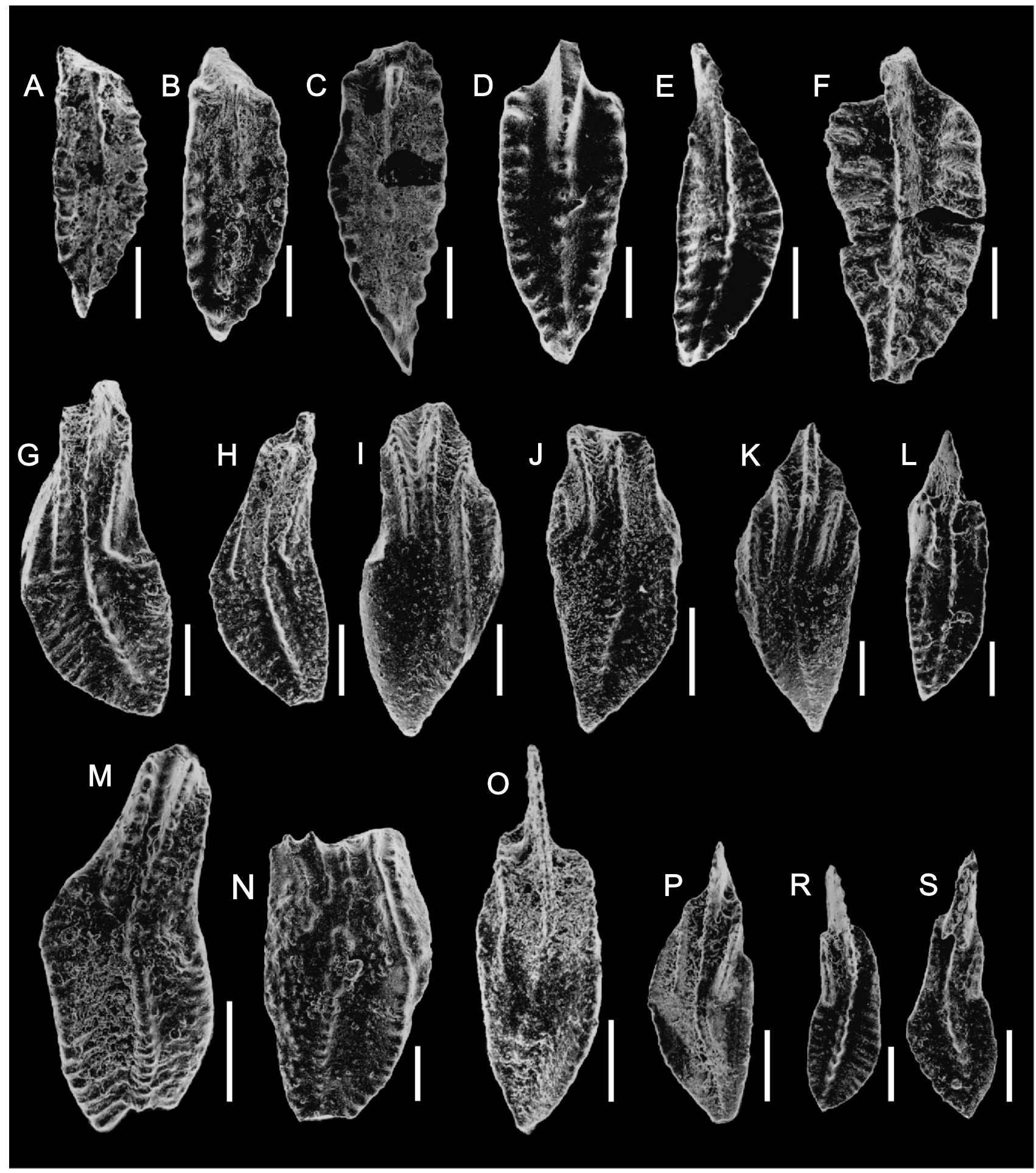

Fig. 6. Siphonodella from the highest Famennian and basal Tournaisian of the Kowala trench

A-C - Siphonodella praesulcata Sandberg: A - sample 145, B - sample 185, C - sample 186; D - Siphonodella ? sp., sample 194; E Siphonodella sulcata (Huddle), sample 184; F - Polygnathus sp., sample 197; G, H, P - Siphonodella cooperi Hass: G, H sample 213, P sample 203; I - Siphonodella belkai Dzik, sample 207; J, O - Siphonodella isosticha (Cooper), sample 193; K - Siphonodella belkai Dzik (Branson and Mehl), sample 207; L, M, R, S - Siphonodella duplicata (Branson and Mehl): L - sample 197, M, R, S - sample 205; N Siphonodella sandbergi Klapper, sample 221; scale bar - $200 \mu \mathrm{m}$ 
Limestones of complex $\mathrm{C}$ contain a low-abundance conodont assemblage (Fig. 3). These taxa are characteristic for a level near the boundary between the praesulcata and sulcata zones (Sandberg et al., 1978; Over, 1992; Kaiser, 2005; Kaiser et al., 2009).

Conodonts Neopolygnathus vogesi (Ziegler), Polygnathus purus purus Voges and Siphonodella sulcata (Huddle) have been identified in the basal part of complex $\mathrm{D}$, about $3 \mathrm{~m}$ above the limestones of complex C (Figs. 3, 5 and 6). The latter taxon indicates the lowermost Tournaisian sulcata Zone (Ziegler and Sandberg, 1984b; Dreesen et al., 1986; Kaiser and Corradini, 2011).

The upper part of the Radlin Beds yields conodont assemblages (Figs. 3, 5 and 6) characteristic of the Lower Tournaisian sulcata-sandbergi zones (Sandberg et al., 1978; Dreesen et al., 1986; Over, 1992; Kaiser, 2005; Kaiser et al., 2009).

Compact claystones located ca. $1.2 \mathrm{~m}$ above the Wocklumeria limestones from complex $\mathrm{B}$, as well as limestones from complex $\mathrm{C}$ contain ammonoids represented by Acutimitoceras prorsum (Schmidt) (Dzik, 1997). The fossils are common in the $22 \mathrm{~cm}$ thick bed of compact claystones of complex $B$ and sporadically in limestones of complex $C$.

In deposits from the Devonian/Carboniferous boundary interval in Kowala, ostracod studies have been made for the upper part of complex A and complexes B, C and D (Olempska, 1997). The recognized taxa include 15 species of planktonic entomozooids and 64 species of benthic ostracodes of the Thuringian ecotype. The assemblage encompassing the latter species contains taxa characteristic of the lowermost Carboniferous, ranging within the sulcata-sandbergi zones, including: Acratia cooperi Gründel, Amphissites centronotus (Ulrich et Bassler), Bairda venterba Gründel, Bohlenatia rhenothuria Becker, Coryellina grandis Robinson, Microcheilinella aculeata Buschmina, Microcheilinella bushminae Olempska, Neocrateria trapezoidalis (Gründel), Ovatoquasillites slowikensis (Olempska), Timorhealdia nitidula nitidula (Richter) and Villozona villosa villosa (Gründel).

Deposits from the Devonian/Carboniferous boundary interval in Kowala have also been subject to microfloral analysis (Filipiak, 2004, 2005; Marynowski and Filipiak, 2007). Five miospore zones (LV, LE, LN, VI, HD), characteristic of the Devonian/Carboniferous boundary interval have been distinguished (Filipiak, 2004). The uppermost Devonian miospore zones (LE? and LN?) were noted in complex B deposits, whereas miospores of zone $\mathrm{VI}$, diagnostic for the Lower Carboniferous, were determined in the lowermost part of complex D (Filipiak, 2004).

Biostratigraphic studies of conodonts and microspores from the Devonian/Carboniferous boundary interval give conformable results. They indicate that the boundary beds between the two systems occur in the lowermost part of the Radlin Beds or in the uppermost part of complex $\mathrm{C}$ (Fig. 3).

The four black shale beds related to the Annulata, Dasberg, Kowala Black Shale and Hangenberg Black Shale have been discriminated in the Upper Famennian sequence of the Kowala Quarry. Their biostratigraphic position, geochemistry and sedimentation conditions, as well as the content of organic matter have been determined (Filipiak and Racki, 2005; Rakociński, 2009, 2011; Marynowski et al., 2010, 2011, 2012a, b; Racka et al., 2010; Kaźmierczak et al., 2012).

The thin Kowala Black Shale layer (Marynowski and Filipiak, 2007) has been correlated with a $30 \mathrm{~cm}$ thick bituminous black shale bed that occurs in a study trench located about $300 \mathrm{~m}$ toward NW (Malec, 1993b). The latter (Fig. 3, bed 51) lies in the lower part of the Middle expansa condont Zone, about $11.5 \mathrm{~m}$ beneath top of the Wocklumeria limestones, whereas the Kowala Black Shale, distinguished in the quarry, occurs about
$7.8 \mathrm{~m}$ beneath this limestone top in the Upper expansa Conodont Zone (Marynowski and Filipiak, 2007; Filipiak and Racki, 2010; Marynowski et al., 2010). The $30 \mathrm{~cm}$ thick bituminous shale that occurs in the study trench seems rather to represent a local horizon situated between the Dasberg shales and Kowala Black Shale, about $1.8 \mathrm{~m}$ above the top of the former ones (refer to Devleeschouwer et al., 2013). In the Devonian-Carboniferous boundary profile exposed in the Kowala study trench, a section of the $\delta^{13} \mathrm{C}$ isotope curve representing the highest value has been found to be closely related to the Hangenberg Event (Trela and Malec, 2007).

\section{JABŁONNA IG 1 BOREHOLE}

The Jabłonna IG 1 borehole was drilled in 1973 in the Borków Syncline located in the southwestern part of the Holy Cross Mountains (Fig. 1). In the interval at the depth of 1.4-88.0 m were drilled Lower Carboniferous and Upper Devonian layers, in which several lithological complexes were determined (Żakowa et al., 1983; Fig. 2):

- 1.4-35.0 m - claystones, pyroclastic rocks, black siliceous claystones, micritic limestones;

- 35.0-55.7 m - siliceous claystones with radiolarians and phosphorites;

- 55.7-62.3 m - claystones with limestone nodules, beds of marly limestones, phosphoritic concretions, intercalations of clay-siliceous rocks and tuffites;

- 62.3-62.6 m - tectonic breccia;

- 62.6-65.8 m - nodular limestones;

- 65.8-67.5 m - micritic limestones;

- 67.5-88.0 m - micritic and organogenic limestones; "różanka" type vein limestones.

Deposits between 1.4-55.7 m represent the Zaręby Beds (Żakowa and Migaszewski, 1995). The strata between 55.7-62.3 $\mathrm{m}$ were assigned to the lowermost Carboniferous (Żakowa et al., 1983). Nodular limestones occurring at 62.6-65.8 $\mathrm{m}$, representing the interval of the Lower praesulcata-Lower marginifera zones, encompass several stratigraphic gaps documented by the lack of several conodont zones (Żakowa et al., 1983; Fig. 2).

Biostratigraphic studies of the Devonian and Carboniferous deposits in the Jabłonna IG 1 borehole were made on the basis of ostracodes (Olempska, 1981), conodonts (Żakowa et al., 1983) and microspores (Filipiak, 2000). At 33.9-34.0 m the conodont Scaliognathus anchoralis Lane and Ziegler occurs, documenting the Upper Tournaisian anchoralis Zone. In the Jabłonna core, this species occur slightly above the top of the complex dominated by radiolarites and clayey-siliceous rocks with phosphorites. The presence of $S$. anchoralis points to the uppermost Carboniferous conodont zone in the Borków Syncline. At $53.5 \mathrm{~m}$, Filipiak (2000) determined the presence of the PC palynozone, and at $50.5 \mathrm{~m}$ - the CM palynozone, encompassing the cuneiformis to anchoralis conodont zones. No conodonts have been encountered at $34.0-58.2 \mathrm{~m}$. These deposits lie probably within the sandbergi to cuneiformis zones. Deposits within 58.2-58.4 m contain the conodonts Siphonodella cooperi Hass, S. obsoleta Hass, S. quadruplicata (Branson and Mehl) and S. duplicata (Branson and Mehl), pointing to the duplicata Zone. At 58.8-61.2 m occur conodonts assigned to the Siphonodella sp., which represent probably the sulcata Zone - the lowermost conodont zone of the Carboniferous. The thickness of strata encompassing the sulcata-duplicata zones reaches ca. $2.5 \mathrm{~m}$. 
The latest Devonian conodonts, documented at 62.3-62.6 m, occur in an assemblage comprising mixed species from the boundary between the Upper expansa to Lower praesulcata zones and the Lower trachytera Zone. Below, at 62.9-63.2 m conodonts documenting the boundary between the Upper expansa and Lower praesulcata zones were noted, at 63.5-63.7 m conodonts of the postera Zone, and at 64.7-65.8 taxa representing the Lower marginifera Zone. Famennian deposits were documented till the depth of $75.0 \mathrm{~m}$, where conodonts belonging to the Middle crepida Zone occur (Żakowa et al., 1983). Isolated conodont assemblages, occurring at 62.3-65.8 $\mathrm{m}$ and recording fragmentary parts of the conodont zones from the Lower praesulcata-Lower marginifera interval, document the presence of several stratigraphic gaps and strong condensation of the middle/uppermost Famennian. Stratigraphic gaps occur in the Middle-Upper praesulcata, Middle expansa, trachytera and Upper-uppermost marginifera zones.

In the Jabłonna IG 1 core, conodonts document the close occurrence of deposits belonging to the uppermost Famennian Lower praesulcata Zone and Lower Tournaisian sulcata or duplicata zones. Conodonts representing the uppermost Famennian Middle to Upper praesulcata zones have not been found. According to Żakowa et al. (1983), the contact between the Famennian and Tournaisian is sedimentary herein, with non-deposition intervals in submarine conditions. This is evidenced by the pelagic character of sediments at the Famennian/Tournaisian boundary.

In comparison to the Famennian succession in the Ostrówka Quarry, the deposits in Jabłonna have a several times larger thickness. The upper part of the Famennian in the Jabłonna core and in the Ostrówka Quarry are similarly condensed. In this part of the succession, mixed fauna of different age and small range stratigraphic gaps are a common case. These phenomena indicate gaps and submarine resedimentation without emersion and direct influence of tectonic factors (Żakowa et al., 1983).

\section{ZARĘBY IG 2 BOREHOLE}

The Zaręby IG 2 borehole was drilled in 1963-1964 in the central part of the Kielce-Łagów Synclinorium near Łagów (Fig. 1). The core encompasses Paleozoic deposits ranging from the Lower Carboniferous to the Lower Cambrian (Jurkiewicz, 1971; Żakowa, 1971a). In the upper part of the succession, encompassing the Devonian/Carboniferous boundary interval, Żakowa (1971a) distinguished several characteristic lithological complexes (Fig. 2):

- 4.0-81.1 m - black siliceous claystones with intercalations of siliceous shales and tufogenic beds;

- 81.1-89.7 m - marls and laminated limestones;

- 89.7-106.6 m - green marls;

- 106.6-173.0 m - marly limestones, marls and marls with limestone nodules;

- 173.0-176.2 m - nodular limestones.

Clayey-siliceous deposits from the topmost part of the core at 4.0-81.1 $\mathrm{m}$ represent the Zaręby Beds (Żakowa, 1971a; Żakowa and Migaszewski, 1995). In the Zaręby IG 2 borehole, the Devonian/Carboniferous boundary was placed at a distinct lithological change, between the carbonates and the clayey-siliceous deposits, at the depth of $81.1 \mathrm{~m}$. According to Jurkiewicz (1971), the contact of these two series is tectonic in nature.

The Late Devonian (Famennian) age of the carbonates and the Early Carboniferous (Tournaisian) age of the clayey-sili- ceous rocks were confirmed by taxonomically diverse microfloral and macrofaunal remains (Jachowicz, 1967; Żakowa, 1971a). Stratigraphically important are bivalves of the genus Guerichia. At 117.6-135.7 m occurs Guerichia cf. simorini (Sadykov) (Żakowa, 1971a). In the Upper Devonian of the Holy Cross Mountains, these bivalves have been recognized in Famennian strata within the Uppermost marginifera to trachytera zones (Żakowa, 1983). Recently, the Devonian/Carboniferous boundary was established in the Zaręby IG 2 core based on palynologic studies (Filipiak, 2004). These have indicated that the microspore assemblages characteristic of the uppermost Devonian, representing palynozone $\mathrm{LN}$, occur in carbonates at the depth of 107.0-109.0 m. In limestones and marls located above, at 81.1-105.0 m, Filipiak (2004) documented Lower Carboniferous microspore assemblages. At 97.0-105.0 $\mathrm{m}$ they represent palynozone $\mathrm{VI}$, and in the topmost part of the succession, at 81.1-95.0 $\mathrm{m}$ - the Lower Tournaisian palynozone HD, corresponding to the sandbergi Zone in the conodont zonation. Microspore studies indicate that the Devonian/Carboniferous boundary in the Zaręby IG 2 borehole is located in the topmost part of marls and laminated limestones, so far assigned to the Famennian (Jurkiewicz, 1971; Żakowa, 1971a). Microspore studies (Filipiak, 2004) indicate that limestones from the interval of 81.1-105.0 m belong to the Lower Tournaisian sulcata-sandbergi conodont zones (Fig. 2).

The lithology of deposits from the Zaręby IG 2 borehole at 81.1-105.0 $\mathrm{m}$ has been erroneously described by Filipiak (2004, 2005), who located radiolaritic shales of the Zaręby Beds in this interval. In reality, at this depth occur limestones and marls (Jurkiewicz, 1971; Żakowa, 1971a). In turn, deposits of the Zaręby Beds have been drilled in the Zaręby IG 2 borehole at $4.0-81.1 \mathrm{~m}$. The core with this part of the succession has been destroyed in 1968.

\section{RUDA STRAWCZYŃSKA BOREHOLE}

The Ruda Strawczyńska borehole was drilled in 1962-1963 in the close western Mesozoic Margin of the Holy Cross Mountains (Fig. 1). Below Permian (Zechstein) conglomerates, at 822.0-1003.6 m Carboniferous as well as Upper Devonian rocks (Pawłowska and Pawłowski, 1978) were drilled, whose lithological characteristics are as follows (Fig. 2):

- 822.0-852.5 m - black siliceous shales, locally sandy, with thin beds of arcosic sandstones; dark grey and grey-cherry red siltstones;

- 852.5-856.2 m - dark grey calcareous dolomicrites with rare, randomly distributed nodules of grey dolomicrites;

- 856.2-857.5 m - black calcareous dolomicrites;

- 857.5-860.6 m - dark grey calcareous dolomicrites with rare, randomly distributed small nodules of grey dolomicrites;

- 860.6-878.3 m - dark grey micritic limestones with randomly distributed light grey limestone nodules;

- 878.3-893.3 m - dark grey micritic limestones with high admixture (up to $50-70 \%$ of the rock volume) of light grey limestone nodules;

- 893.3-915.5 m - bioclastic limestones with shell beds composed of the brachiopods Dzieduszyckia kielcensis Roemer;

- 915.5-967.0 m - nodular limestones composed of micritic limestone nodules of various sizes (up to $10 \mathrm{~cm}$ across), composing $20-50 \%$ of the rock volume, distributed within the grey-black marly deposits; 
- 967.0-1003.6 m - grey-black marls, locally dolomitized, with corals, brachiopods, crinoids and bryozoans.

Deposits occurring at 822.0-852.5 m represent the Lower Carboniferous Zaręby Beds. Based on macrofauna, they have been assigned to the Upper Tournaisian Ammonellipsites goniatite Zone (upper Tn3) (Żakowa, 1981; Żakowa and Migaszewski, 1995), corresponding to the upper Tournaisianlowermost Visean Fascipericyclus-Ammonellipsites goniatite Zone (Korn and Feist, 2007; Tilsley and Korn, 2009; Korn and Kaufmann, 2009). The carbonates occurring below, at 852.5-1003.6 $\mathrm{m}$, have been assigned by Pawłowska and Pawłowski (1978) to the Frasnian and Famennian. According to these authors, there is a stratigraphic gap and angular unconformity of about $20^{\circ}$ between the Devonian and Carboniferous layers. Based on conodont studies by Kościelniakowska (in Pawłowska and Pawłowski, 1978), the Frasnian/Famennian boundary has been placed in this borehole at $915.5 \mathrm{~m}$. New conodont data document that the Frasnian/Famennian boundary is located in this borehole lower than hitherto assumed (Malec, 2009), which is indicated by the Frasnian conodonts Palmatolepis subrecta Miller et Youngquist and Ancyrodella sp., recognized at 953.2 m and Famennian conodonts: Palmatolepis minuta minuta Branson et Mehl and $P$. glabra lepta Ziegler et Huddle in samples from 929.5 m (e.g., Klapper and Ziegler, 1979; Ziegler and Sandberg, 1984a, 1990).

A more precise position of the Frasnian/Famennian boundary in this succession is documented by Kościelniakowska (Pawłowska et al., 1972) by the presence of ten specimens of Palmatolepis triangularis Sannemann at $940.2 \mathrm{~m}$ (Fig. 2). This taxon is indicative of the triangularis Zone, the lowermost conodont zone of the Famennian (Ziegler and Sandberg, 1990). The presented data demonstrate that the Frasnian/Famennian boundary lies in the Ruda Strawczyńska section most probably slightly beneath $940.2 \mathrm{~m}$.

At $901.1 \mathrm{~m}$ the following conodonts were noted: Palmatolepis perlobata schindewolfi (Muller) and P. glabra lepta Ziegler et Huddle. The co-occurrence of these conodonts ranges from the Lower marginifera-Upper trachytera zones (Klapper and Ziegler, 1979; Ziegler and Sandberg, 1984a).

The brachiopods Dzieduszyckia kielcensis Roemer from the depth of 893.3-915.5 m, represented the mass occurrence of this fauna in Poland (Biernat, 1967, 1988; Pawłowska and Pawłowski, 1978).

In the upper part of the carbonate deposits occurs a sparse conodont assemblage pointing to the Upper Famennian: at 871.5-889.0 m - Palmatolepis gracilis gracilis Branson et Mehl, at $873.5-874.5 \mathrm{~m}-$ Bispathodus stabilis (Branson et Mehl), and at 870.5-871.5 m - B. aculeatus aculeatus (Branson et Mehl). The latter taxon ranges from the Middle expansa-Upper praesulcata zones of the uppermost Famennian to the lower part of the Lower Tournaisian sulcata Zone (Klapper and Ziegler, 1979; Ziegler and Sandberg, 1984a; Dreesen et al., 1986). According to Kaiser (2005), its ranges into the sandbergi Zone.

In the topmost part of the carbonates, above the conodont samples, at 853.7-863.0 m occur numerous ostracode assemblages (a total of 21 species), represented by the Thuringian ecotype deep-water benthic forms (Malec, 2009). Among them, eight species: Healdia thuringensis Gründel, Rectonaria muelleri Gründel, Rectonaria varica Gründel, Bairda feliumgibba Becker, Rectonaria inclinata Gründel, Timorhealdia nitidula nitidula (Richter), Orthonaria rectagona (Gründel) and Paraberounella thuringica Gründel - have been noted in successions across the Devonian/Carboniferous boundary both in the uppermost Famennian as well as in the Lower Tournaisian. The remaining ostracodes, represented by the species: Bairda venterba Gründel, Acratia cooperi Gründel, Healdianella cf. bispinosa Gründel, Microcheilinella cf. bushmina Olempska, Aurigerites blumenstengeli nigermontanus Lethiers and Feist, Paraberounella cuneata (Gründel), P. gattendorfina Gründel, Paragerodia spinosa Wang, Orthonaria neotridentifer Lethiers et Feist, Famenella angulata perparva Lethiers et Feist, Triplacera (Necrateria) trapezoidalis Gründel, Aurigerites cf. obernitzensis Gründel and Spinela cf. prebitannensis Lethiers et Feist, are characteristic of the Lower Tournaisian (Gründel, 1961, 1962, 1973: Blumenstengel, 1965, 1979, 1993; Becker, 1976, 1987; Olempska, 1979, 1981, 1997; Bartzsch and Weyer, 1986; Wang, 1988; Lethiers and Feist, 1991; Becker et al., 1993). Part of the Lower Carboniferous species from the Ruda Strawczyńska core have also been recognized in the Kowala succession, where they occur within the range of the sulcatasandbergi Conodont zones (Olempska, 1997). Analysis of the ostracode stratigraphic ranges indicates that at $853.7-863.0 \mathrm{~m}$ Lower Carboniferous species from the sulcata-sandbergi zones appear. Therefore, in the Ruda Strawczyńska section, the Devonian/Carboniferous boundary occurs lower than hitherto accepted, most probably below $863.0 \mathrm{~m}$, in the upper part of micritic limestones with nodular limestones. The Devonian/Carboniferous boundary beds are represented by deep-water carbonates characterized by continuous sedimentation.

Results of biostratigraphic studies of the Zaręby Beds (Żakowa and Migaszewski, 1995) and the carbonates lying directly below in the Ruda Strawczyńska core indicate that there is a stratigraphic gap of tectonic nature between the two rock series, encompassing the crenulata-Upper anchoralis/Lower texanus conodont zones (Fig. 2).

\section{CONDITIONS OF SEDIMENTATION}

The Devonian/Carboniferous boundary interval has been documented only in the Kielce Region of the Holy Cross Mountains, from Zaręby in the east to the vicinity of Gałęzice and Ruda Strawczyńska in the west (Fig. 1). In this area, the Upper Devonian and Lower Carboniferous facies development was largely controlled by the structure of the basement. The southern part of the Kielce Region with a firmer basement was during the Middle and Late Devonian, till the Late Frasnian, the area of a shallow-water carbonate platform. From the north it was bounded by a deeper basin, i.e. the Kostomłoty facies zone, located approximately within the Kielce-Łagów Synclinorium. Both in the Late Devonian and at the Devonian/Carboniferous boundary, the highest gradient in the facies development was noted from the south to the north, between the carbonate platform and the Kostomłoty zone with basinal facies (Narkiewicz, 1988; Racki, 1993; Szulczewski, 1995).

On the carbonate platform, Late Devonian and Early Carboniferous sedimentation was controlled by synsedimentary block movements of the basement. This influence resulted in the deposition of different facies and thicknesses within submarine horsts and grabens, distributed mostly in the central and northern part of the Kielce Region. Deposits on the seamounts, are developed as condensed, thin-bedded, dark grey and black pelagic limestones with cephalopods and crinoids (Szulczewski, 1978, 1995; Szulczewski et al., 1996). Commonly the fauna is concentrated in cephalopod shell beds. These areas were periodically subject to the activity of waves or currents, causing a larger concentration of shells and their preferred orientation. In the mixed crinoid-cephalopod facies, the segregation of organic remains was induced by storm waves. Sedimentation of condensed complexes, with breaks in deposition in the submarine settings, ranged from the Upper Frasnian rhenana 
Zone to the Middle/Upper Tournaisian in the western part of the Kielce region in the Ostrówka Quarry area (Szulczewski, 1981; Fig. 2). Deposits with mixed conodont assemblages, containing forms characteristic of several conodont zones, are often present. Lack of deposits from the Devonian/Carboniferous boundary in some areas is also documented by neptunian dykes containing conodonts documenting their primary deposition (Szulczewski, 1973). Upper Devonian condensed beds laterally pass into marly-limestone basinal facies or various types of detrital limestones. In the Chęciny-Zbrza intrashelf basin of the Kielce region several black bituminous beds assigned to the Middle Famennian through the Devonian-Carboniferous boundary have been recorded (Filipiak and Racki, 2005; Racki, 2006; Rakociński, 2011). They correspond to the Famennian Annulata, Dasberg, Kowala Black Shale and Hangenberg Black Shale of global and local extent (Walliser, 1996; House, 2002; Marynowski and Filipiak, 2007; Filipiak and Racki, 2010; Racka et al., 2010; Marynowski et al., 2010, 2012a, b; Kaźmierczak et al., 2012).

The Lower Carboniferous (Tournaisian) successions occur in sedimentary continuity on the Famennian carbonates and developed as deep-water carbonates - marly claystones with limestone nodules and thin intercalations of pyroclastic rocks. They have been distinguished in the western part of the Holy Cross Mountains as the Radlin Beds (Żakowa and Pawłowska, 1961, 1966; Żakowa, 1981; Malec, 1993a, b, 1995; Szulczewski, 1995; Żakowa and Migaszewski, 1995). The beginning of their sedimentation was in the Lower sulcata Zone and lasted most probably to the upper part of the sandbergi Zone (Figs. 2 and 3).

The region of Gałęzice with the Ostrówka Quarry, located in the western part of the Gałęzice-Bolechowice Syncline, was an active tectonic block in Late Devonian and Early Carboniferous times. Sedimentation of condensed deposits with several large stratigraphic gaps took place on an emerging seamount at the Devonian/Carboniferous boundary (Szulczewski, 1978, 1981; Fig. 2). In the region of Ostrówka, the Lower Carboniferous carbonates represented by the Radlin Beds are characterized by high stratigraphic condensation. The beginning of their sedimentation in most sections took place in the anchoralis Zone. In some of them, characterized by a more complete Famennian succession, the deposits range from the sandbergi to the texanus zones (Szulczewski et al., 1996; Skompski et al., 2006). Higher up in the Carboniferous succession they pass with sedimentary continuity into siliceous claystones of the Zaręby Beds (Fig. 2).

In the northern, Kostomłoty facies zone, the Devonian/Carboniferous boundary beds recognized in the Zaręby IG 2 and Ruda Strawczyńska boreholes are represented by marls and pelagic limestones that originated in a basinal setting. Sedimentation of the Lower Tournaisian carbonates, corresponding to the Radlin Beds, was in the lower sulcata-sandbergi zones, similarly as in the western part of the Kielce Region (Fig. 2). These deposits pass, most probably with sedimentary continuity, into the clayey-siliceous rocks of the Zaręby Beds. At present, the observed contact of these series is tectonic in nature. According to biostratigraphic data, the chronostratigraphic boundary between the Devonian and Carboniferous lies within the upper part of the carbonates (Fig. 2).

Litho- and biostratigraphic analysis of the sequence from the Devonian/Carboniferous boundary interval indicates that in the Kielce Region of the Holy Cross Mountains, the clayey-siliceous deposits of the Lower Carboniferous Zaręby Beds never lie in sedimentary continuity on the uppermost Devonian (Famennian) carbonates. So far it was assumed that in several areas of the Kielce Region there is a sedimentary continuity of the uppermost Famennian carbonates and the Zaręby Beds (Żakowa, 1981; Żakowa and Migaszewski, 1995). In the Kielce Region of the Holy Cross Mountains and their western Mesozoic Margin, the deposition of the Zaręby Beds commenced in the lower part of the crenulata Zone (apart from the Gałęzice area with the Ostrówka Quarry, where these sediments appeared in the texanus Zone). In the Gałęzice area (Ostrówka Quarry), the sedimentation of these deposits lasted most probably to the middle part of the bilineatus Zone (Fig. 2).

\section{DEVONIAN/CARBONIFEROUS BOUNDARY INTERVAL IN KOWALA AND THE RHENISH MASSIF}

The best recognized Devonian/Carboniferous boundary beds of the Holy Cross Mountains occur at Kowala. Their lithological characteristics indicate large similarities to deposits from the Devonian/Carboniferous boundary interval of the Rhenish Massif. Moreover, succeeding types of sediments appear in similar biostratigraphic intervals (Walliser, 1984; Ziegler and Sandberg, 1984b; Clausen et al., 1989; Malec and Migaszewski, 1992; Bless et al., 1993; Malec, 1993a, b, 1995; Becker, 1996; Dzik, 1997; Filipiak, 2004). Limestones with Wocklumeria from the topmost part of complex A in Kowala correspond to the Wocklum Limestone from the Rhenish Massif. In both areas, sedimentation of the topmost part of these deposits finished near the boundary between the Upper Famennian Lower/Middle praesulcata zones (Figs. 3 and 7; Kürschner et al., 1993; Becker, 1996; Walliser, 1996; Kaiser et al., 2009). Claystones from complex B in Kowala have equivalents in the Rhenish Massif represented by the Hangenberg Black Shale and Hangenberg Sandstone (Fig. 7). A claystone interval with quartz wacke beds of the Kowala complex $B$ corresponds to the Hangenberg Sandstone in the Rhenish Massif area. In both areas, the upper part of the claystones contain an ammonoid fauna with Acutimitoceras prorsum (Schmidt), which is the index taxon of the prorsum Zone, the uppermost Devonian ammonoid zone in the Rhenish Massif (Korn, 1993; Becker, 1996; Dzik, 1997). The biostratigraphic position of limestones from the complex $C$ in Kowala indicates their similarity to the Stockum Limestone (Ziegler and Sandberg, 1984b; Bless et al., 1988, 1993; Becker and Paproth, 1993; Becker, 1996; Kaiser et al., 2011). The lithology and stratigraphic position of carbonates from complex $\mathrm{D}$ in Kowala (Radlin Beds) indicate their correspondence to the Hangenberg Limestone, whose sedimentation in the Rhenish Massif begins in the lower part of the sulcata Zone (Higgs and Streel, 1984; Ziegler and Sandberg, 1984b; Becker, 1996; Walliser, 1996). Siliceous claystones from complex E (Zaręby Beds) in Kowala correspond to the black claystones known as the Alum Shale (Liegende Alaunschiefer) from the Rhenish Massif; in both areas these deposits appear in the lower part of the crenulata Zone (Bless et al., 1993; Malec, 1993b, 1995; Becker, 1996; Fig. 7).

\section{EVENT STRATIGRAPHY AND CONODONT BIOFACIES AT THE DEVONIAN/CARBONIFEROUS BOUNDARY}

The large similarity of the lithological development of the Devonian/Carboniferous boundary beds in Kowala and successions from the Rhenish Massif indicates common geological factors. Apart from similar lithologies, the disappearance and appearance of various faunal groups took place in the same 
Rheinisches

Schiefergebirge

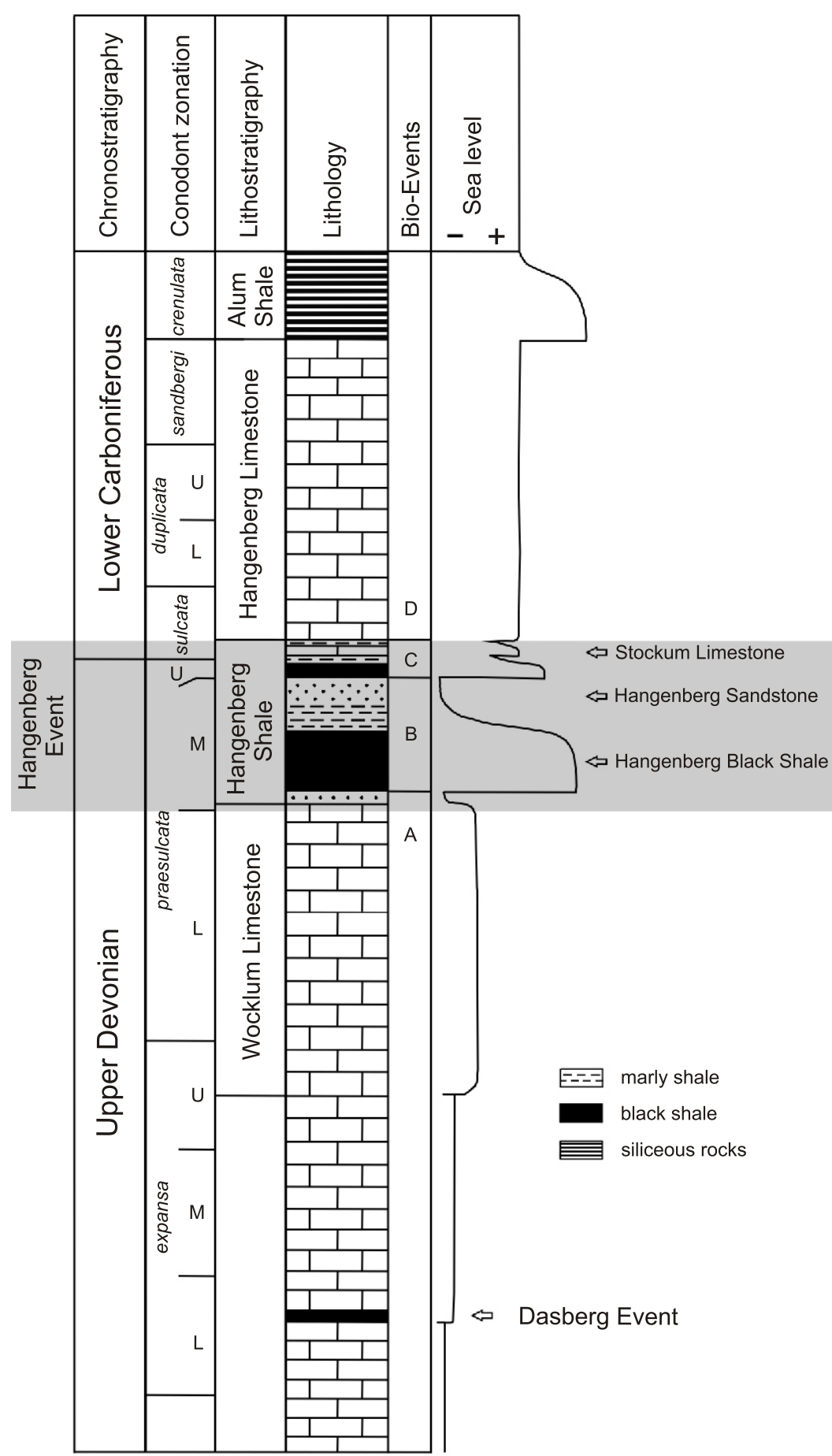

Holy Cross Mountains

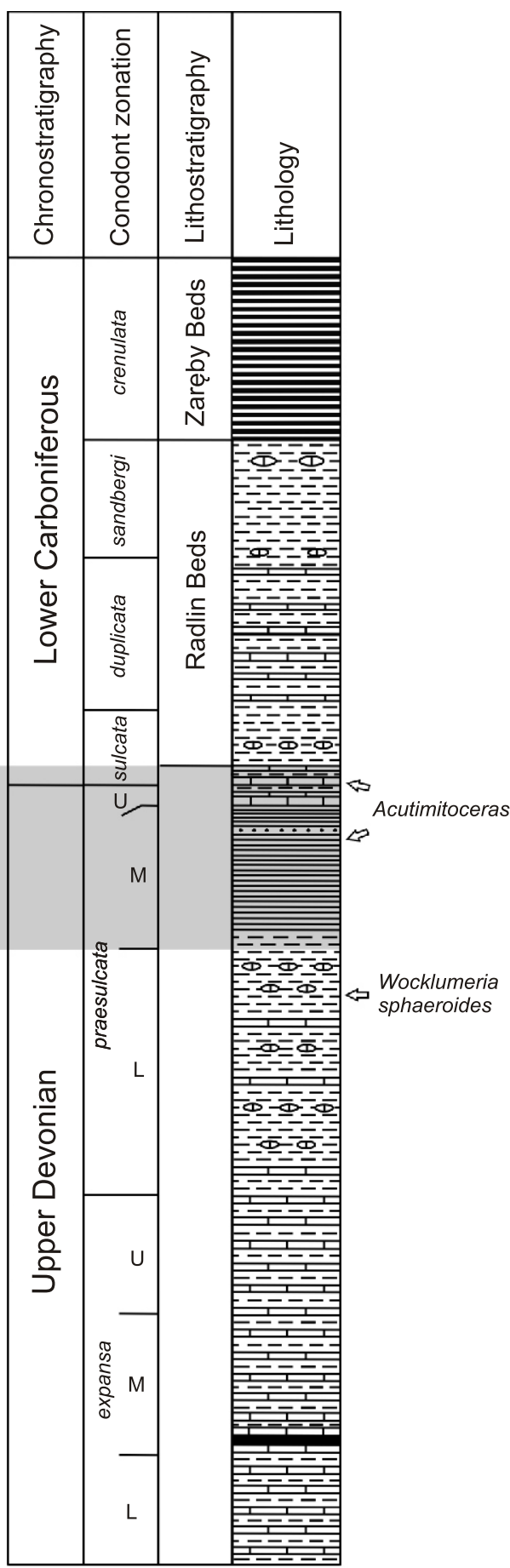

Fig. 7. Correlation of the Devonian/Carboniferous beds from the Rheinisches Schiefergebirge (after Higgs and Streel, 1984; Bless et al., 1993; Walliser, 1996; Kaiser et al., 2006) and Holy Cross Mountains (exploratory trench in Kowala) 
time intervals in both areas, the latter usually in similar lithological horizons. Relatively rapid lithological changes in the Devonian/Carboniferous boundary beds as well as perturbations in the biota from this time have been documented in many regions of the world and attributed to eustatic sea level changes linked with a regression and transgression (House, 1983, 2002; Johnson et al., 1985; Becker, 1993; Racki, 1997; Kaiser et al., 2006, 2008, 2011; Devleeschouwer et al., 2013). Biotic transformations at the Devonian/Carboniferous boundary, reflected by the extinction of many organisms, have been determined as the Hangenberg Event (Walliser, 1984, 1985, 1996) or Hangenberg Crisis (Kaiser et al., 2011), which marks the last appearance of the goniatite Wocklumeria sphaeroides and ranges till the first appearance of the species Gattendorfia subinvoluta (Becker, 1993, 1996; Walliser, 1996). The mass extinction was triggered by transgression and anoxia (Kaźmierczak et al., 2012), which followed the warming and transgressive event of the Hangenberg Black Shale.

In the Rhenish Slate Mountains, the sedimentation of the Hangenberg Black Shale took place during the early Hangenberg Event (Walliser, 1984; House, 2002). Several subordinate transgressive-regressive cycles as well as four (A-D) biotic events are distinguished within this event (Bless et al., 1993; Kaiser et al., 2011; Fig. 7).

The Event $A$, which corresponds to the upper section of Wocklum Limestone sedimentation, determines a general decrease in faunal diversity induced by a regressive episode. The Event B begins an anoxic episode (Hangenberg Black Shale) connected with a short-lived transgression and massive extinction, after which a great regressive episode occurred. The Event $C$ from the boundary between the praesulcata and sulcata zones is characterized by "replacement" of Devonian faunal assemblages by Carboniferous assemblages, whereas the Event $D$ from the boundary between the sulcata and duplicata zones - by fast radiation and expansion of Carboniferous fauna.

The Hangenberg Event (Hangenberg Crisis) was caused by global climatic fluctuations connected with major eustatic sea level changes, with highest amplitude just before Devonian/Carboniferous boundary (Becker, 1996; Kaiser et al., 2011; Kalvoda et al., 2013). This phenomenon was linked with a large-scale glacial episode in the southern hemisphere, causing relatively rapid sea level fall (Streel et al., 2000; Sandberg et al., 2002; Caputo et al., 2008; Isaacson et al., 2008; Kaiser et al., 2011; Kalvoda et al., 2013; Kumpan et al., 2013).

In the Kowala profile, interval with quartz wacke beds distinguished within the claystone complex $(\mathrm{B})$, corresponds to the maximum regressive phase in the Hangenberg Event that relates with the main period of Gondwana glaciations.

The Devonian-Carboniferous boundary clearly falls in the time of new minor post-glacial transgression, and carbonate sedimentation in pelagic conditions, with appearance of new faunal assemblages among cephalopods, trilobites, conodonts and entomozoacean ostracodes (Flajs and Feist, 1988; Bless et al., 1993; Becker, 1996; Kaiser et al., 2006, 2008, 2009, 2011). The younger, major transgressive episode is accompanied by the Middle Tournaisian deposition of the Lower Alum Shale Event in the Rhenish Slate Mountains (Becker, 1993, 1996; Walliser, 1996) and Zaręby Beds in the Holy Cross Mountains (Fig. 7).

Fluctuations related to transgressive and regressive episodes in the Late Devonian and Early Carboniferous, which are reflected in the conodont biofacies pattern (e.g., Dreesen, 1992; Walliser, 1996; Kaiser et al., 2008; Kalvoda et al., 2013), are also marked in the Kowala profile. In this place within Middle-Upper expansa zones, conodont assemblages are pre- dominated by the palmatolepid-bispathodus biofacies, which are linked to the basinal area and the lower part of its slope (e.g., Sandberg and Dreesen, 1984; Dreesen et al., 1986; Dreesen, 1992). At the boundary of the Upper expansa and Lower praesulcata zones, the conodont biofacies consists mainly of individual organisms assigned to the genera Palmatolepis and Bispathodus with subordinate Branmehla, Pseudopolygnathus and Siphonodella. In the upper part of Fammenian limestones with Wocklumeria of the Kowala profile (Lower praesulcata Zone), i.e. at the beginning of Hangenberg Event, nearly all conodonts of the genus Palmatolepis became extinct. The only species $P$. gracilis sigmoidalis was found in the limestones of the complex C (Upper praesulcata Zone; Fig. 3). Most species of the genus Bispathodus disappear in the Lower praesulcata Zone. The Upper praesulcata and Lower sulcata zones contain only $B$. stabilis and $B$. aculeatus aculeatus (Fig. 3). In other areas, the bispathodus and palmatolepid biofacies predominated up to the Middle praesulcata Zone (e.g., Clausen at al., 1989; Kaiser et al., 2008). Only individual species of the genus Bispathodus passed into the Upper praesulcata, sulcata and duplicata zones (Luppold et al., 1984; Perret, 1988; Over, 1992; Nemirovskaya et al., 1993; Kaiser, 2005; Kalvoda et al., 2013).

No conodonts assigned to the Middle praesulcata Zone have been found in claystones of the complex B of the Kowala profile (Fig. 3). In this profile conodonts of the genus Prothognathodus occur in the Upper praesulcata Zone within limestones of the complex $\mathrm{C}$. The presence of these conodonts is connected with the Late Devonian transgression, during which adaptative radiation took place (Becker, 1996; Kaiser et al., 2008). The protognathodid biofacies is ascribed to the outer shelf environment and the basinal slope (Kalvoda et al., 1999) or to the shallower sea environment (Dreesen, 1992).

In the Lower Carboniferous Kowala profile the conodont assemblages are represented by the siphonodellid-polygnathid biofacies, which are characteristic of the pelagic environment of the outer shelf (Flajs and Feist, 1988; Kalvoda et al., 1999). In the Kowala profile, the contribution of conodonts assigned to the genus Siphonodella increases substantially from the duplicata Zone (Dzik, 1997). The rapid increase in the amount of conodonts belonging to the siphonodellid biofacies in the duplicate Zone was noted in Carboniferous profiles of different areas (e.g., Clausen et al., 1989; Walliser, 1996; Kaiser et al., 2008). This is elucidated by a raise of sea level (Kalvoda et al., 2013).

\section{SUMMARY}

The paper characterizes the Devonian/Carboniferous boundary beds in five sections from the Holy Cross Mountains and one located at its nearby Mesozoic Margin (Fig. 1). In four of them: Ruda Strawczyńska, Bolechowice IG 1, Zaręby IG 1 and Kowala, the Devonian/Carboniferous boundary, biostratigraphically documented by conodonts, ostracodes and microspores, lies within a continuous succession of deep-water carbonates. In the two remaining sections: Ostrówka Quarry and Jabłonna IG 1, the boundary between the systems is characterized by stratigraphic gaps caused by lack of deposition in submarine conditions (Szulczewski, 1981; Żakowa et al., 1983; Szulczewski et al., 1996).

Continuous sedimentation of marls and carbonates from the Devonian/Carboniferous boundary interval lasted till the Lower Tournaisian sandbergi Zone (Fig. 2). In the western part of the Holy Cross Mountains, Lower Carboniferous carbonates have been distinguished as the Radlin Beds (Żakowa, 1981; Żakowa 
and Migaszewski, 1995). They pass with sedimentary continuity into siliceous claystones of the Zaręby Beds. Apart from the Ostrówka section, where their sedimentation began in the Lower Visean texanus Zone, in the remaining part of the Holy Cross Mountains these deposits appeared earlier in the Carboniferous, in the Middle Tournaisian crenulata Zone (Fig. 2).

In the Kowala section, the sequence from the Devonian/Carboniferous boundary interval is strikingly similar to contemporary strata from the Rhenish Massif. In both areas, the same biostratigraphic intervals are characterized by the same lithofacies and faunal assemblages. The simultaneous appear- ance of similar deposits was caused by common factors, linked with global sea level fluctuations, resulting from glaciations on the southern hemisphere (see Sandberg et al., 2002; Caputo et al., 2008; Isaacson et al., 2008).

The conodont biofacies succession in Kowala is the same as in the other $\mathrm{D} / \mathrm{C}$ profiles in Europe.

Acknowledgements. The author would kindly like to thank Dr. A. Żylińska and Prof. Z. Migaszewski for translating the text to English, and also Dr. P Filipiak and anonymous reviewer for their very helpful remarks.

\section{REFERENCES}

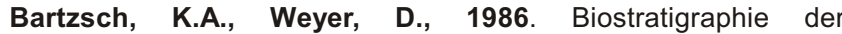
Devon/Karbon-Grenze im Bohlen-Profil bei Saalfeld (Thüringen, DDR). Zeitschrift für Geologische Wissenschaften, 14: $147-152$

Becker, G., 1976. Thüringian ostracods from the Famennian of the Cantabrian Mountains (Upper Devonian, N. Spain). Sixth International Ostracod Symposium, Saalfelden: 459-474.

Becker, G., 1987. Ostracoda des Thüringer Ökotyps aus dem grenzbereich Devon/Karbon N-Africa (Marokko, Algerien). Palaeontographica, A 200: 45-104.

Becker, G., Clausen, C.D., Leuterits, K., 1993. Verkieselte Ostracoden von Thüringer Ökotyp aus dem Grenzbereich Devon/Karbon des Steinbruchs Drewer (Rheinisches Schiefergebirge). Courier Forschungsinstitut Senckenberg, 160: $1-131$

Becker, R.T., 1993. Analysis of ammonoid palaeogeography in relation to the global Hangenberg (terminal Devonian) and Lower Alum Shale (Middle Tournaisian) Events. Annales Societe Geologique Belgique, 115: 459-473.

Becker, R.T., 1996. New faunal records and holostratigraphic correlation of the Hasselbachtal D/C boundary auxiliary stratotype (Germany). Annales Societe Geologique Belgique, 117: 19-45.

Becker, R.T., Paproth, E., 1993. Auxiliary stratotype section for the global stratotype section and point (GSSP) for the Devonian-Carboniferous boundary: Hasselbachtal. Annales Societe Geologique Belgique, 115: 703-706.

Bełka, Z., Skompski, S., 1988. Mechanizm sedymentacji i pozycja facjalna wapienia weglowego w południowo-zachodniej części Gór Świętokrzyskich (in Polish with English summary). Przegląd Geologiczny, 36: 442-448.

Belka, Z., Skompski, S., Soboń-Podgórska, J., 1996. Reconstruction of a lost carbonate platform on the shelf of Fennosarmatia: evidence from Visean polymictic debrite, Holy Cross Mountains, Poland. Geological Society Special Publications, 107: 315-329.

Biernat, G., 1967. New data on the genus Dzieduszyckia Siemiradzki, 1909 (Brachiopoda). Acta Palaeontologica Polonica, 12: 133-155.

Biernat, G., 1988. Famennian brachiopods of the Holy Cross Mountains, Poland. Canadian Society of Petroleum Geologists Memoirs, 14: 327-335.

Bless, M.J.M., Simakov, K.V., Streel, M., 1988. Advantages and disadvantages of a conodont-based or event-stratigraphic Devonian-Carboniferous Boundary. Courier Forschungsinstitut Senckenberg, 100: 3-14.

Bless, M.J.M., Becker, R.T., Higgs, K., Paproth, E., Streel, M., 1993. Eustatic cycles around the Devonian-Carboniferous boundary and the sedimentary and fossil record in Sauerland (Federal Republic of Germany). Annales Societe Geologique Belgique, 115: 689-702.
Blumenstengel, H., 1965. Zur Taxonomie und Biostratigraphie verkieselter Ostracoden aus dem Thüringer Oberdevon. Freiberger Forschungshefte, C 183: 1-127.

Blumenstengel, H., 1979. Die Ostracodenfauna der Wocklumeria-Stufe (Oberdevon) bei Saalfeld im Thüringer Schiefergebirge. Zeitschrift für Geologische Wissenschaften, 7: 521-557.

Blumenstengel, H., 1993. Ostracodes from the Devonian-Carboniferous boundary beds in Thuringia (Germany). Annales Societe Geologique Belgique, 115: 483-489.

Caputo, M.V., Melo, J.H.G., Streel, M., Isbell, J.L., 2008. Late Devonian and Early Carboniferous glacial records of South America. GSA Special Paper, 441: 1-13.

Clausen, C.D., Leuteritz, K., Ziegler, W., 1989. Ausgewählte Profile an der Devon/Karbon-Grenze im Sauerland (Rheinisches Schiefergebirge). Fortschritte in der Geologie von Rheinland und Westfalen, 35: 161-226.

Czarniecki, S., 1973. Goniatites from Carboniferous Limestone at Gałęzice (Holy Cross Mountains) (in Polish with English summary). Rocznik Polskiego Towarzystwa Geologicznego, 43: 227-248.

Czarniecki, S., 1992. Warunki sedymentacji karbonu Gałęzic. Przegląd Geologiczny, 40: 604-605.

Czarnocki, J., 1916. Kilka słów o odkryciu utworów karbońskich w Górach Świętokrzyskich. Sprawozdanie z Posiedzeń Towarzystwa Naukowego Warszawskiego, 8: 952-964.

Czarnocki, J., 1928. Przegląd stratygrafii famenu i karbonu dolnego (kulmu) w zachodniej i środkowej części Gór Świętokrzyskich. Posiedzenia Naukowe Państwowego Instytutu Geologicznego 21: 55-59.

Czarnocki, J., 1933. Stratygrafia warstw granicznych między dewonem i karbonem w okol. Kowali. Posiedzenia Naukowe Państwowego Instytutu Geologicznego, 34: 31-34.

Czarnocki, J., 1950. Geology of the Łysa Góra region (Święty Krzyż Mountains) in connection with the problem of iron ores at Rudki (in Polish with English summary). Prace Państwowego Instytutu Geologicznego, 1: 1-404.

Czarnocki, J., 1989. Clymeniids of the Góry Świettokrzyskie Mts. (in Polish with English summary). Prace Państwowego Instytutu Geologicznego, 127: 1-91.

Davydov, V., Wardlaw, B.R., Gradstein, F.M., 2004. The Carboniferous period. In: A Geologic Time Scale 2004 (eds. F.M. Gradstein, J.G. Ogg and A.G. Smith): 222-248. Cambridge University Press, Cambridge.

Devleeschouwer, D., Rakociński, M., Racki, G., Bond, D.P.G. Sobień, K., Claeys, P., 2013. The astronomical rhythm of Late-Devonian climate change (Kowala section, Holy Cross Mountains, Poland). Earth and Planetary Science Letters, 365 : 25-37.

Dreesen, R., 1992. Conodont biofacies analysis of the Devonian/Carboniferous Boundary Beds in the Carnic Alps. Jahrbuch der Geologischen Bundesanstalt, 135: 49-56. 
Dreesen, R., Sandberg, C.A., Ziegler, W., 1986. Review of Late Devonian and Early Carboniferous conodont biostratigraphy and biofacies models as applied to the Ardenne Shelf. Annales Societe Geologique Belgique, 109: 27-42.

Dzik, J., 1997. Emergence and succession of Carboniferous conodont and ammonoid communities in the Polish part of the Variscan sea. Acta Palaeontologica Polonica, 42: 57-170.

Dzik, J., 2006. The Famennian "Golden Age" of conodonts and ammonoids in the Polish part of the Variscan sea. Palaeontologia Polonica, 63: 1-360.

Fedorowski, J., 1971. Aulophyllidae (Tetracoralla) from the Upper Visean of Sudetes and Holy Cross Mountains. Palaeontologia Polonica, 24: 1-137.

Filipiak, P., 2000. New palynological data on the Upper Tournaisian from the Borków Syncline in the Holy Cross Mountains (Jabłonna IG 1, Central Poland) (in Polish with English summary). Przegląd Geologiczny, 48: 1156-1159.

Filipiak, P., 2004. Miospore stratigraphy of Upper Famennian and Lower Carboniferous deposits of the Holy Cross Mountains (central Poland). Review of Palaeobotany and Palynology, 128: 291-322.

Filipiak, P., 2005. Late Devonian and Early Carboniferous acritarchs and prasinophytes from the Holy Cross Mountains (central Poland). Review of Palaeobotany and Palynology, 134: $1-26$.

Filipiak, P., Racki, G., 2005. Unikatowy zapis dewońskich zdarzeń beztlenowych w profilu kamieniołomu Kowala k. Kielc. Przegląd Geologiczny, 53: 846-847.

Filipiak, P., Racki, G., 2010. Proliferation of abnormal palynoflora during the end-Devonian biotic crisis. Geological Quarterly, $\mathbf{5 4}$ (1): 1-14.

Flajs, G., Feist, R., 1988. Index conodonts, trilobites and environment of the Devonian-Carboniferous Boundary beds at La Serre (Montagne Noire, France). Courier Forschungsinstitut Senckenberg, 100: 53-107.

Freyer, G., Żakowa, H., 1967. Famennian conodonts from borehole Bolechowice 1 (in the Holy Cross Mts). Acta Geologica Polonica, 17: 105-136.

Gradstein, F.M., Ogg, J.G., 2004. Geologic Time Scale 2004 - why, how, and where next! Lethaia, 37: 175-181.

Gründel, J., 1961. Zur Biostratigraphie und Fazies der Gattendorfia-Stufe in Mitteldeutschland unter besonderer Berücksichigung der Ostracoden. Freiberger Forschungshefte, C 111: 54-144.

Gründel, J., 1962. Zur Taxionomie der Ostracoden der Gattendorfia-stufe Thüringes. Freiberger Forschungshefte, C 151: $51-97$.

Gründel, J., 1973. Bythocytheridae (Ostracoda) aus dem Oberdevon/Dinant des Thüringer Schiefergebirges. Zeitschrift für Geologische Wissenschaften, 1: 329-340.

Higgs, K., Streel, M., 1984. Spore stratigraphy at the Devonian-Carboniferous boundary in the northern "Rheinisches Schiefergebirge", Germany. Courier Forschungsinstitut Senckenberg, 67: 157-179.

House, M.R., 1983. Devonian eustatic events. Proceedings of the Ussher Society, 5: 396-405.

House, M.R., 2002. Strength, timing, setting and cause of mid-Palaeozoic extinctions. Palaeogeography, Palaeoclimatology, Palaeoecology, 181: 5-25.

Isaacson, P.E., Diaz-Martinez, E., Grader, G.W., Kalvoda, J., Babek, O., Devuyst, F.X., 2008. Late Devonian - earliest Mississippian glaciation in Gondwanaland and its biogeographic consequences. Palaeogeogaphy, Palaeoclimatology, Palaeoecology, 268: 126-142.

Jachowicz, A., 1967. Mikroflora of the Zareby Beds from Świętokrzyskie Mountains (in Polish with English summary). Prace Instytutu Geologicznego, 49: 1-108.

Johnson, J.G., Klapper, G., Sandberg, C.A., 1985. Devonian eustatic fluctuations in Euroamerica. GSA Bulletin, 96: 567-587.
Jurkiewicz, H., 1971. The deep geological structure of the Łagów area (in Polish with English summary). Biuletyn Instytutu Geologicznego, 242: 5-27.

Jurkiewicz, H., Żakowa, H., 1978. Algae and foraminiferida of the Upper Visean from the Gałęzie Syncline (in Polish with English summary). Prace Instytutu Geologicznego, 85: 1-72.

Kaiser, S.I., 2005. Mass extinctions, climatic and oceanographic changes at the Devonian/Carboniferous boundary. Ph.D. thesis. Ruhr-Universität Bochum.

Kaiser, S.I., Corradini, C., 2011. The early siphonodellids (conodonta, Late Devonian - Early Carboniferous): overview and taxonomic state. Neues Jahrbuch für Geologie und Paläontologie Abhandlungen, 261: 19-35.

Kaiser, S.I., Steuber, T., Becker, R.T., Joachimski, M.M., 2006 Geochemical evidence for major environmental change at the Devonian-Carboniferous boundary in the Carnic Alps and the Renish Massif. Palaeogeography, Palaeoclimatology, Palaeoecology, 240: 146-160.

Kaiser, S.I., Steuber, T., Becker, R.T., 2008. Environmental change during the Late Famennian and Early Tournaisian (Late Devonian-Early Carboniferous): implications from stable isotopes and conodont biofacies in southern Europe. Geological Journal, 43: 241-260.

Kaiser, S.I., Becker, R.T., Spalletta, T., Steuber, T., 2009. High-resolution conodont stratigraphy, biofacies, and extinctions around the Hangenberg event in pelagic successions from Austria, Italy, and France. Palaeontographica Americana, 63: 99-138.

Kaiser, S.I., Becker, R.T., Steuber, T., Aboussalam, S.Z., 2011. Climate-controlled mass extinctions, facies, and sea-level changes around the Devonian-Carboniferous boundary in the eastern Anti-Atlas (SE Morocco). Palaeogeography, Palaeoclimatology, Palaeoecology, 310: 340-364.

Kalvoda, J., Babek, O., Malovana, A., 1999. Sedimentary and biofacies records in calciturbidites at the Devonian-Carboniferous Boundary in Moravia (Moravian-Silesian Zone, Middle Europe). Facies, 41: 141-158.

Kalvoda, J., Kumpan, T., Babek, O., 2013. Upper Famennian and Lower Tournaisian sections of the Moravian Karst (Moravo-Silesian Zone, Czech Republic): a proposed key area for correlation of the conodont and foraminiferal zonations. Geological Journal. DOI: 10.1002/gj.2523

Kaufmann, B., 2006. Calibrating the Devonian Time Scale: A synthesis of U-Pb ID-TIMS ages and conodont stratigraphy. Earth-Science Reviews, 76: 175-190.

Kaźmierczak, J., Kremer, B., Racki, G., 2012. Late Devonian marine anoxia challenged by benthic cyanobacterial mats in Kellwasser and Hangenberg mass extinction horizons. Geobiology, 10: 371-383.

Klapper, G., Ziegler, W., 1979. Devonian conodont biostratigraphy. Special Papers in Palaeontology, 23: 199-224.

Korn, D., 1993. The ammonoid faunal change near the Devonian-Carboniferous boundary. Annales Societe Geologique Belgique, 115: 581-593.

Korn, D., Feist, R., 2007. Early Carboniferous ammonoid faunas and stratigraphy of the Montagne Noire (France). Fossil Record, 10: 99-124.

Korn, D., Kaufmann, B., 2009. A high-resolution relative time scale for the Visean stage (Carboniferous) of the Kulm Basin (Rhenish Mountains, Germany). Geological Journal, 44: 306-321.

Kumpan, T., Babek, O., Kalvoda, J., Fryda, J., Grygar, T.M., 2013. A high-resolution, multiproxy stratigraphic analysis of the Devonian-Carboniferous boundary sections in the Moravian Karst (Czech Republic) and a correlation with the Carnic Alps (Austria). Geological Magazine. DOI: 10.1017/S0016756812001

Kürschner, W., Becker, R.T., Buhl, D., Veizer, J., 1993. Strontium isotopes in conodonts: Devonian-Carboniferous transition, the northern Rhenish Slate Mountains, Germany. Annales Societe Geologique Belgique, 115: 595-621.

Kwiatkowski, S., 1959. The Carboniferous Limestone of Gałęzice (in Polish with English summary). Biuletyn Instytutu Geologicznego, 159: 5-51. 
Lethiers, F., Feist, R., 1991. Ostracodes, stratigraphie et bathymetrie du passage Devonien-Carbonifere au Viseen inferieur en Montagne Noire (France). Geobios, 24: 71-104.

Luppold, F.W., Hahn, G., Korn, D., 1984. Trilobiten-, Ammonoideenund Conodonten - Stratigraphie des Devon/Karbon - Grenzprofiles auf dem Müssenberg (Rheinisches Schiefergebirge). Courier Forschungsinstitut Senckenberg, 67: 91-121.

Łydka, K., Żakowa, H., 1975. The environments of Carboniferous sedimentation at Gałęzie (in Polish with English summary). Biuletyn Instytutu Geologicznego, 283: 101-149.

Malec, J., 1993a. Profil z pogranicza dewonu i karbonu w Kowali (informacje wstępne). Posiedzenia Naukowe Państwowego Instytutu Geologicznego, 49: 71-72.

Malec, J., 1993b. Stop 1A: Devonian-Carboniferous boundary at Kowala. In: Global Boundary Events. An Interdisciplinary Conference Kielce, Poland, September 27-29, 1993. Excursion Guidebook: 10-11.

Malec, J., 1995. Devonian/Carboniferous boundary. In: XIII International Congress on Carboniferous-Permian, August 28-September 2, Guide to Excursion B4: evolution of the Polish-Moravian carbonate platform in the Late Devonian and Early Carboniferous, Holy Cross Mts., Kraków Upland, Moravian Karst (eds. M. Szulczewski and J. Dvorak): 15-16.

Malec, J., 2009. Uwagi o stratygrafii dewonu i karbonu w profilu otworu Ruda Strawczyńska 1. Posiedzenia Naukowe Państwowego Instytutu Geologicznego, 65: 31-32.

Malec, J., Migaszewski, Z., 1992. Wstępne dane o profilu pogranicza dewonu i karbonu w Kowali. Przegląd Geologiczny, 40: 607.

Malec, J., Tarnowska, M., Lenartowicz, L., Fijałkowska, A., Turnau, E., Romanek, A., Filipiak, P., 1995. Korelacje litostratygraficzne, biostratygraficzne i geochemiczne utworów dewonu w Górach Świętokrzyskich. Narodowe Archiwum Geologiczne, no. 1330/96, Warszawa.

Marynowski, L., Filipiak, P., 2007. Water column euxinia and wildfire evidence during deposition of the Upper Famennian Hangenberg event horizon from the Holy Cross Mountains (central Poland). Geological Magazine, 144: 569-595.

Marynowski, L., Filipiak, P., Zatoń, M., 2010. Geochemical and palynological study of the Upper Famennian Dasberg event horizon from the Holy Cross Mountains (central Poland). Geological Magazine, 147: 527-550.

Marynowski, L., Kurkiewicz, S., Rakociński, M., Simoneit, B.R.T., 2011. Effects of weathering on organic matter: I. Changes in molecular composition of extractable organic compounds caused by paleoweathering of a Lower Carboniferous (Tournaisian) marine black shale. Chemical Geology, 285:144-156.

Marynowski, L., Trela, W., Salwa, S., 2012a. Stop 1. Kowala Famennian black shale horizons and Devonian/Carboniferous boundary. In: Geoshale 2012: recent advances in geology of fine-grained sediments. 14-16 May 2012 Warsaw, Poland Book of abstracts field trip guidebook (eds. P. Lis et al.) 168-170. International Conference organized by Polish Geological Institute-National Research Institute.

Marynowski, L., Zatoń, M., Rakociński, M., Filipiak, P., Kurkiewicz, S., Pearce, T.J., 2012b. Deciphering the upper Famennian Hangenberg Black shale depositional environments based on multi-proxy record. Palaeogeography, Palaeoclimatology, Palaeoecology, 297: 549-575.

Narkiewicz, M., 1988. Turning points in sedimentary development in the Late Devonian in southern Poland. Canadian Society of Petroleum Geologists, Memoir, 14: 619-635.

Narkiewicz, M., Racki, G., Wrzołek, T., 1990. Lithostratigraphy of the Devonian stromatoporoid-coral carbonate sequence in the Holy Cross Mountains (in Polish with English summary). Kwartalnik Geologiczny, 34 (3): 433-456.

Nehring-Lefeld, M., 1990. Famennian biostratigraphy of the Kowala borehole on the basis of conodonts (in Polish with English summary). Kwartalnik Geologiczny, 34 (2): 271-290.

Nemirovskaya, T.I., Chermnykh, V.A., Kononova, L.I., Pazukhin, V.N., 1993. Conodonts of the Devonian-Carboniferous bound- ary section, Kozhim, Polar Urals, Russia. Annales Societe Geologique Belgique, 115: 629-647.

Olempska, E., 1979. Middle to Upper Devonian ostracoda from the southern Holy Cross Mountains, Poland. Palaeontologia Polonica, 40: 57-162.

Olempska, E., 1981. Lower Carboniferous ostracodes of the Holy Cross Mountains, Poland. Acta Palaeontologica Polonica, 26: 35-53.

Olempska, E., 1997. Changes in benthic ostracod assemblages across the Devonian-Carboniferous boundary in the Holy Cross Mountains, Poland. Acta Palaeontologica Polonica, 42: 291-332.

Osmólska, H., 1962. Famennian and Lower Carboniferous Cyrtosymboline (Trylobita) from the Holy Cross Mountains, Poland. Acta Paleontologica Polonica, 7: 53-222.

Over, D.J., 1992. Conodonts and the Devonian-Carboniferous boundary in the upper Woodford Shale, Arbuckle Mountains, south-central Oklahoma. Journal of Paleontology, 66: 293-311.

Pawłowska, K., Pawłowski, S., 1978. The characteristics of Paleozoic (Carboniferous and Devonian) deposits on the basis of borehole profile from Ruda Strawczyńska (in Polish with English summary). Kwartalnik Geologiczny, 22 (4): 679-691.

Pawłowska, K., Kubica, B., Pawłowski, S., 1972. Budowa geologiczna niecki promnickiej. Otwór Ruda Strawczyńska. Archiwum Geologiczne Oddziału Świętokrzyskiego PIG-PIB, no. 2109, Kielce.

Perret, M.F., 1988. Le passage du Devonien au Carbonifere dans les Pyrenees. Courier Forschungsinstitut Senckenberg, 100 39-52.

Racka, M., Marynowski, L., Filipiak, P., Sobstel, M., Pisarzowska, A., Pearce, T.J., 2010. Anoxic Annulata Events in the Late Famennian of the Holy Cross Mountains (Southern Poland): Geochemical and palaeontological record. Palaeogeography, Palaeoclimatology, Palaeoecology, 297: 549-575.

Racki, G., 1993. Evolution of the bank to reef complex in the Devonian of the Holy Cross Mountains. Acta Palaeontologica Polonica, 37: 87-182.

Racki, G., 1997. Devonian eustatic fluctuations in Poland. Courier Forschungsinstitut Senckenberg, 199: 1-12.

Racki, G., 2006. Świętokrzyski zapis globalnych zdarzeń biotycznych. In: Procesy i zdarzenia w historii geologicznej Gór Świętokrzyskich (eds. S. Skompski and A. Żylińska). Przewodnik 77 Zjazdu Polskiego Towarzystwa Geologicznego, Ameliówka k. Kielc, 28-30 czerwca 2006: 63-64. Państwowy Instytut Geologiczny, Warszawa

Rakociński, M., 2009. Dolnokarboński zapis zdarzeń beztlenowych oraz aktywności wulkanicznej w profilu kamieniołomu Kowala koło Kielc. Przegląd Geologiczny, 57: 1046-1047.

Rakociński, M., 2011. Gdy Ziemia wstrzymała oddech. Rocznik Muzeum Ewolucji, 3: 10-19.

Romanek, A., Rup, M., 1990. Lithostratigraphic subdivision of the Devonian sequence in the Kowala 1 borehole (in Polish with English summary). Kwartalnik Geologiczny, 34 (2): 221-242.

Rubinowski, Z., Rup, M., Zbroja, S., 1983. Wstępna informacja o wynikach wiercenia Kowala 1 w Górach Świętokrzyskich. Kwartalnik Geologiczny, 27 (4): 887-888.

Sandberg, C.A., Dreesen, R., 1984. Late Devonian icriodontid biofacies models and alternate shallow-water conodont zonation. GSA Special Paper, 196: 143-178.

Sandberg, C.A., Ziegler, W., Leuteritz, K., Brill, S.M., 1978. Phylogeny, speciation, and zonation of Siphonodella (Conodonta, Upper Devonian and Lower Carboniferous). Newsletters on Stratigraphy, 7: 102-120.

Sandberg, C.A., Morrow, J.R., Ziegler, W., 2002. Late Devonian sea-level changes, catastrophic events, and mass extinction. GSA Special Paper, 356: 473-487.

Skompski, S., 1992. Kamieniołom Ostrówka. In: XV Konferencja Paleontologów. Paleontologiczny zapis zdarzeń późnego dewonu i karbonu. Przewodnik wycieczkowy Ostrówka Kostomłoty - Wietrznia. Bocheniec 1992: 1-4.

Skompski, S., 2006. Karbon Gór Świętokrzyskich. In: Procesy i zdarzenia w historii geologicznej Gór Świętokrzyskich (eds. S. 
Skompski and A. Żylińska). Przewodnik 77 Zjazdu Polskiego Towarzystwa Geologicznego, Ameliówka k. Kielc, 28-30 czerwca 2006: 65-66. Państwowy Instytut Geologiczny, Warszawa.

Skompski, S., Szulczewski, M., 2000. Lofer-type cyclothems in the Upper Devonian of the Holy Cross Mts. (central Poland). Acta Geologica Polonica, 50: 393-406.

Skompski, S., Szulczewski, M., Konon, A., 2006. Stanowisko 4 Kamieniołom Ostrówka. Wycieczka 4: Dewon zachodniej części Gór Świętokrzyskich (Bukowa Góra- MogiłkiWietrznia-Ostrówka). In: Procesy i zdarzenia w historil geologicznej Gór Świętokrzyskich (eds. S. Skompski and A Żylińska). Przewodnik 77 Zjazdu Polskiego Towarzystwa Geologicznego, Ameliówka k. Kielc, 28-30 czerwca 2006: 15-18. Państwowy Instytut Geologiczny, Warszawa.

Streel, M., Caputo, M.V., Loboziak, S., Melo, J.H.G., 2000. Late Frasnian-Famennian climates based on palynomorph analyses and the question of the Late Devonian glaciation. Earth-Science Reviews, 52: 121-173.

Szulczewski, M., 1971. Upper Devonian conodonts, stratigraphy and facial development in the Holy Cross Mts. Acta Geologica Polonica, 21: 1-129.

Szulczewski, M., 1973. Famennian-Tournaisian neptunian dykes and their conodont fauna from Dalnia in the Holy Cross Mts. Acta Geologica Polonica, 23: 15-59.

Szulczewski, M., 1978. The nature of unconformities in the Upper Devonian-Lower Carboniferous condensed sequence in the Holy Cross Mts. Acta Geologica Polonica, 28: 283-298.

Szulczewski, M., 1981. Stratygrafia utworów dewonu i dolnego karbonu w kamieniołomie Ostrówka. In: Przewodnik 53 Zjazdu Polskiego Towarzystwa Geologicznego, Kielce 6-8 września 1981: 193-197.

Szulczewski, M., 1982. Principal problems of the Devonian stratig raphy in Poland (in Polish with English summary). Biuletyn Geologiczny Uniwersytetu Warszawskiego, 25: 267-297.

Szulczewski, M., 1995. Depositional evolution of the Holy Cross Mts. (Poland) in the Devonian and Carboniferous - a review. Geological Quarterly, 39 (4): 471-488.

Szulczewski, M., Skompski, S., 1995. Stop 4. Ostrówka quarry. In: XIII International Congress on Carboniferous-Permian, August 28-September 2, Guide to Excursion B4: evolution of the Polish-Moravian carbonate platform in the Late Devonian and Early Carboniferous: Holy Cross Mts., Kraków Upland, Moravian Karst (eds. M. Szulczewski and J. Dvorak): 20-23.

Szulczewski, M., Żakowa, H., 1976. New data on the Famennian of the Gałęzie Syncline (in Polish with English summary). Biuletyn Instytutu Geologicznego, 296: 51-73.

Szulczewski, M., Belka, Z., Skompski, S., 1996. The browning of a carbonate platform: an example from the Devonian-Carboniferous of the southern Holy Cross Mountains, Poland. Sedimentary Geology, 106: 21-49.

Tilsley, J.W., Korn, D., 2009. Chadian (Tournaisian-Visean, Carboniferous) ammonoids from the Milldale Limestone Formation of the southern Peak District, England. Proceedings of Yorkshire Geological Society, 57: 217-234.

Trela, W., Malec, J., 2007. Carbon isotope record in sediments of the Devonian-Carboniferous boundary in the southern Holy Cross Mountains (in Polish with English summary). Przegląd Geologiczny, 55: 411-415.

Turnau, E., 1985. Devonian-Carboniferous boundary in the borehole Kowala 1 (Southern Holy Cross Mts, Poland); Spores. Bulletin of the Polish Academy of Science, Earth Sciences, 33: 2-5.

Turnau, E., 1990. Spore zones of Famennian and Tournaisian deposits from the Kowala 1 borehole (in Polish with English summary). Kwartalnik Geologiczny, 34 (2): 291-304.

Walliser, O.H., 1984. Pleading for a natural D/C boundary. Courier Forschungsinstitut Senckenberg, 67: 241-246.

Walliser, O.H., 1985. Natural boundaries and Commission boundaries in the Devonian. Courier Forschungsinstitut Senckenberg, 75: 401-408
Walliser, O.H., 1996. Global Events in the Devonian and Carboniferous. In: Global Events and Event Stratigraphy in the Phanerozoic (ed. O.H. Walliser): 225-250. Springer, Berlin.

Wang, S., 1988. Ostracode fauna from the Early Carboniferous Wangyou formation in Nandan of Guangxi and their paleoecotype. Memoirs of Nanjing Institute of Academia Sinica, 24: 269-315.

Wendt, J., Kaufmann, B., Belka, Z., Korn, D., 2009. Carboniferous stratigraphy and depositional environments in the Ahnet Mouydir area (Algerian Sahara). Facies, 55: 443-472.

Wolska, Z., 1967. Devonian conodonts from the south-west region of the Holy Cross Mountains, Poland (in Polish with English summary). Acta Palaeontologica Polonica, 12: 363-435.

Ziegler, W., Sandberg, C.A., 1984a. Palmatolepis-based revision of upper part of standard Late Devonian conodont zonation. GSA Special Paper, 196: 179-193.

Ziegler, W., Sandberg, C.A., 1984b. Important candidate sections for stratotype of conodont based Devonian-Carboniferous boundary. Courier Forschungsinstitut Senckenberg, 67: 231-239.

Ziegler, W., Sandberg, C. A., 1990. The Late Devonian standard conodont zonation. Fifth European Conodont Symposium (ECOS V). Courier Forschungsinstitut Senckenberg, 121: $1-115$.

Zakowa, H., 1967. The Lower Carboniferous from the vicinity of Bolechowice (Holy Cross Mts.) (in Polish with English summary). Acta Geologica Polonica, 17: 51-103.

Żakowa, H., 1970. The present state of the stratigraphy and paleogeography of the Carboniferous in the Holy Cross Mts. Acta Geologica Polonica, 20: 3-32.

Żakowa, H., 1971a. New data on the stratigraphy of the uppermost Devonian (Famennian) and the Carboniferous (Tournaisian) of the Łagów syncline (Góry Świętokrzyskie, central Poland) (in Polish with English summary). Biuletyn Państwowego Instytutu Geologicznego, 242: 61-102.

Żakowa, H., 1971b. Zone Goniatites granosus in the Gałęzie syncline (Góry Świętokrzyskie) (in Polish with English summary). Prace Państwowego Instytutu Geologicznego, 60: $1-137$.

Żakowa, H., 1976. Some problems of the Carboniferous in the Gałęzice Syncline (in Polish with English summary). Biuletyn Instytutu Geologicznego, 296: 5-40.

Żakowa, H., 1981. Rozwój i stratygrafia karbonu Gór Świętokrzyskich. In: Przewodnik 53 Zjazdu Polskiego Towarzystwa Geologicznego, Kielce 6-8 września 1981: 89-100.

Żakowa, H., 1983. The genus Guerichia Rzehak, 1910 (Bivalvia) from the Famennian and Tournaisian deposits of Jabłonna, Góry Świętokrzyskie Mts., Poland (in Polish with English summary). Biuletyn Instytutu Geologicznego, 345: 177-223.

Żakowa, H., Migaszewski, Z., 1995. Góry Świętokrzyskie Mts. Prace Państwowego Instytutu Geologicznego, 148: 109-119.

Żakowa, H., Paszkowski, M., 1989. Pozycja stratygraficzna warstw zarębiańskich (karbon dolny) w Górach Świętokrzyskich. Kwartalnik Geologiczny, 33 (2): 376-377.

Żakowa, H., Pawłowska, J., 1961. The Lower Carboniferous in the area between Radlin and Górno in the Kielce-Łagów synclinorium (Święty Krzyż Mountains) (in Polish with English summary). Biuletyn Instytutu Geologicznego, 167: 101-166.

Żakowa, H., Pawłowska, J., 1966. The Carboniferous of the Miedziana Góra syncline (in Polish with English summary). Biuletyn Instytutu Geologicznego, 195: 5-64.

Żakowa, H., Szulczewski, M., Chlebowski, R., 1983. The Upper Devonian and Carboniferous of the Borków syncline (in Polish with English summary). Biuletyn Instytutu Geologicznego, 345: 5-134

Żakowa, H., Nehring-Lefeld, M., Malec, J., 1985. Devonian-Carboniferous boundary in the borehole Kowala 1 (southern Holy Cross Mts, Poland). Macro- and microfauna. Bulletin of the Polish Academy of Sciences, Earth Sciences, 33: 87-95. 